AÜIFD Cilt XLIII (2002) Sayt 2 s.91-119

\title{
Kur'ân-1 Kerim'de Hz. Peygamber'e Hitaplar (I)
}

\section{Muhammed Fatih KESLER}

Doç. Dr., Çanakkale Onsekiz Mart Üniversitesi İlâhiyat Fakültesi

Speaches to Prophet Mohammad in Quran(I). What has been done in this two-sectioned study is to present and analyze the modes and features of the Qur'ânic calls which institute, reorganize and overrule the behavioral moulds, cognitive forms, social and communal attitudes of the prophet of Islam, in particular; and socio-religious fabric and behavioral codes of the Early Islamic Community, in general. These Qur'ânic calls which are the subject matter of this study are order (emir), caution (ikaz), relieve (teselli), remember (hattrlatma), threat (tehdit), advice (tavsiye), and inform (bilgilendirme). In this first section of this study, the four of these calls will be presented and evaluated, the rest will be subject matter of another study. As exercised over other messengers and apostles throughout the history of revelation before, this Divine method categorically preserves and reinforces the infallibility of the Prophet of Islam--save some minor mistakes-- and, thus, of the Revelatory role model as represented in the moral expressions of him. Hence, overriding all contrary speculations and disputes over the Prophet being a moral and social model, these features of the prophet prove that his practices and discourses are to be emulated and practiced as reinstituted by the Qur'ânic calls during the Revelatory Era. Succinctly, the Divine call reconstitutes its subject, i.e. the Prophet, via revelatory calls; then, the prophetic traditions reconstruct the community accordingly.

Key Words: The Qur'ân, Prophet, the calls, exegesis. 


\section{Giriş}

İki ayrı makale olarak sunduğumuz bu çalışmanın konusu kısaca; $\mathrm{Hz}$. Peygamber'in çeşitli konulardaki düşünce ve davranışlarına, âile ilişkilerine ve diğer insanlarla olan münasebetlerindeki tasarruflarına işaret eden Kur'ân'ın bazı hitap şekilleri ile, bu hitaplardaki bir takım müdahalelerin incelenmesinden ibârettir.

Kur'ân'ın tamamı aslında Hz. Peygamber'e ve onun şahsında bütün muhataplara yöneltilen bir hitaptır. Bu kutsal hitabın gerek içeriğinde gerekse sunuluş biçimindeki çeşitlilik İlâhî irâdenin bir tasarrufu ve dünyada olup bitenlere yaptığı birer müdahalesidir. Tenzil sürecinde sıkça başvurulan bu yöntem, toplumdaki bazı yanlışlıkların düzeltilmesi hususunda muhataplar açısından birtakım kolaylıklar da sağlamıştır. Muhtevalarında birer müdahaleyi taşıyan bu hitaplann üzerinde durduklan konular, yöneltildikleri

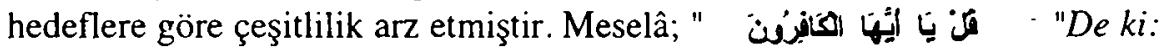
Ey kâfirler!"ı nidası ile başlayan bir hitabın konusu, muhatap alınan grupların öncelikli olarak inanç konusundaki yanlışlıklarına şu veya bu şekilde yapılan açık birer müdahaledir. Bu olgu, inanmayan insanlann öteden beri devam ettire geldikleri batıl inançlarının izâlesi için kaçınılmaz olmuştur. Aynı

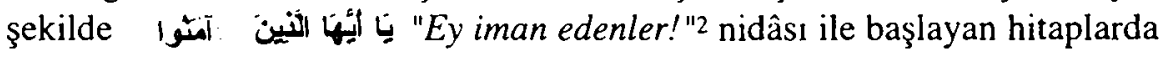
da, yukandaki örneklerden farklı bile olsa bir takım müdahalelerin varlığı sabittir. Medine döneminde olgunlaşma süreci geçiren İslâm Toplumu'nda karşılaşılan bir takım zor meselelerin yanı sıra gerek Müslümanlar ve gerekse İslâm dışı unsurlar tarafından Peygamber (a.s.)'e yöneltilen bazı müşkil sorular da yine bu müdahaleler vesilesiyle çözümlenebilmiştir. Kur'ân'ın, zinde gücü konumundaki bu bildirimlerde başlıca iki yol izlenmiştir: Bunlardan birincisi, bazı ibadetlerin farz kılınması gibi daha önce toplumda mevcut olmayan bir hususun ortaya konulması, ikincisi ise, aynı toplumda önceden beri mevcut olan ve sürdürülen bir takım yanlışlara işâret edilerek onların yerlerine konulması gereken doğruların önerilmesi ve benzeri şeylerdir.

Kur'ân'daki genel hitapların dışındaki öznel hitaplar ve bunlarda mevcut olan müdahaleler bazen de, vahyin tebliğcisi ve her şeye rağmen bir beşer olan Muhammed (a.s.)'e yöneltilmiştir. Ancak hem muhtevâ hem de vermek istedikleri mesaj açısından yukarıda bahsettiğimiz örneklerden tamamen farklı olan bu hitaplar inkarcılara yöneltilenlerde mevcut olan,

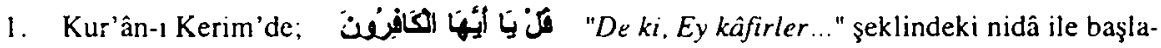
yan bazı âyetler için bkz: Tahrîm (66): 7; Kâfirûn (109):1.

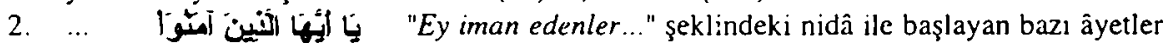
için bkz: Bakara (2):153; I-i I mrân (3): 100, 102; Nisâ (4): 19. 
tehdit ve aşağılama gibi olguların yerine, bir insan olarak Elçi'nin davranışlanna yansıyan olumsuzlukları yumuşak bir şekilde izâle etmeyi yeğleyen bir üslûba sahiptirler. Meselâ $\mathrm{Hz}$. Peygamber'in ilk vahyi aldığı esnada gösterdiği aceleciliğe daha başlangıçta İlâhî irâde tarafından bu tarzda bir müdahale yapılmış ve bu beşerî durumun, onun kalbinde Kur'ân'ın istikrar bulmasına engel olamayacağı garanti edilmiştir:

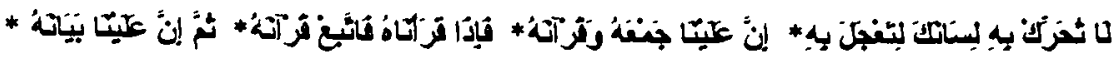

"(Ey Muhammed!) onu hemen okumak için dilini depretme. Onu (senin kalbinde) toplamak ve (sana) okumak bize dïsser. O halde sana Kur'ân't okuduğumuz zaman onun okunuşunu takip et. Sonra onu açıklamak da bize düser."

Bu Ilâhî hitapta, Kur'ân'ın İlâhî bağlamda korunmasının yanı sıra onu insanlara ulaştıran Elçi'nin de korunduğu vurgulanmaktadır. Gerek Kur'ân'ı Kerim'in ${ }^{4}$ gerekse onu getiren Elçi'nin korunmasına yönelik ${ }^{5}$ olarak yapılan diğer vahiy eksenli vaatleri de göz önünde bulundurursak, Muhammed (a.s.)'in bir takım İlâhî müdahalelere maruz kalmasının sebeplerini daha iyi anlayabiliriz. Onun bütün insanlara peygamber ve örnek bir şahsiyet olarak gönderilmesi ${ }^{7}$ gibi her beşere ve hatta her peygambere nasip olmayan özelliklerle donatılması, gerektiği zaman kendisinin düşünce ve fiillerine yapılabilecek bu türden müdahaleleri zorunlu kılmıştır. Diğer taraftan Kurân'ın bu kesitlerine olumsuz anlamlar yüklemek de söz konusu değildir; zîra vahiy tarihinde diğer peygamberler üzerinde de pratize edilen bu yöntem ${ }^{8}$ Son Peyzamber'in değerini düşürmemiş aksine ona, Ilâhî bir gözetim ve koruma altında bulunan dolayısıyla bazı küçük hatalar

3. Kiyâmet (75): 16-19.

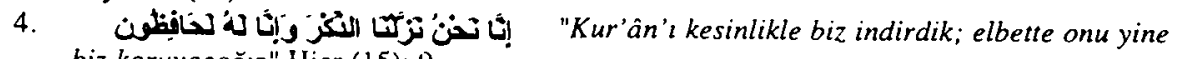
biz koruyacağız" Hicr (15): 9.

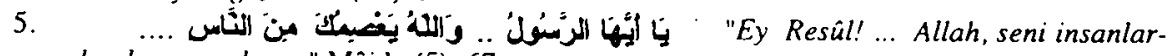
dan koruyacakur..." Mâide (5): 67.

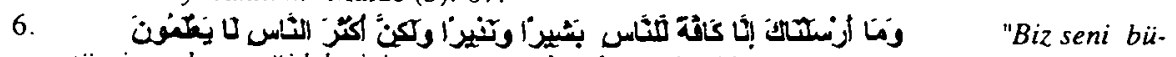
tün insanlara müjdeleyici ve uyarıcı olarak gönderdik; fakat insanların foğu bilmezler" Sebe (34): 28.

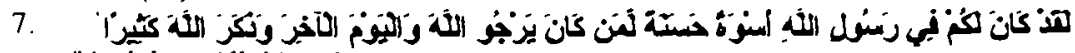
"Andolsun Allah'in elf̧isinde size Allah'، ve ahireti arzu eden. O'nu çok anan kimselere (uyulacak) en güzel örnek vardır " Ahzâb (33): 21.

8. Bu konuyla ilgili olarak Kur'ân-ı Kerim'de Hz. Yûsuf hakkında yer alan şu ibâreler bâriz bir örnek oluşturmaktadır:

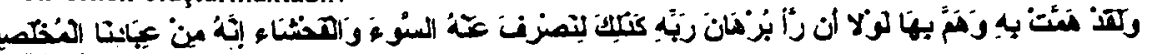

"Andolsun kı kadin ona meyletti. Eğer Rabb'inin burhânını görmeseydi o da kadına meyledecekti. Işte böylere biz, kötülük ve fuhşu ondan uzaklaştırmak için (delillerimizi gösterdik). Cünkii o, ihlâsa erdirilmiş kullarımızdandı. Yûsuf (12): 24. 
dışında ${ }^{9}$ günah işlemeyen seçkin bir kul kimliği kazandırmıştır. Bu gerçek, Son Peygamber'in her hareketinin niçin örnek alınması gerektiği hususunda zihinlerde oluşabilecek tereddütlere de en güzel cevaptır. Tabi ki o bir beşerdir ama her beşere verilmeyen bir takım ayrıcalıklarla desteklenmiş, dolayısıyla farklı bir kimlikle kendisine "ismet sıfatı" kazandınımı̧tır. Bu aşamadan sonra onun, yaptığı eylemlerinde kayıtsız kalmaması ${ }^{10}$ bir bakıma kendisine teslim edilen Kur'ân'ın doğru anlaşılması için gerekli olmuştur. Bu aynı zamanda nebevî aktiviteler arasında yer almaması gereken ancak bazı sebeplere binâen Peygamber (a.s.)'e ait olan ayak sürçmelerinin mü'minler tarafından ayırt edilmeleri için de bir zorunluluktur. İşte hayatın bütün bu yansımaları, Peygamber (a.s.)'e İlâhî bağlamda zaman zaman yapılan hitaplardaki müdahalelerin haklı gerekçelerini oluşturmuştur.

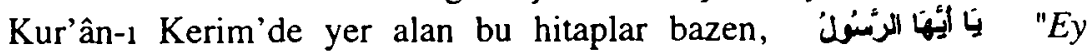

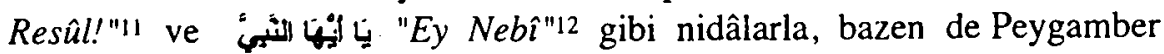
(a.s.)'e yönelik zamir'13 ve benzeri şekillerde gerçekleşmiştir. Ancak biz, burada Allah Resûlû'ne risâlet hayatı boyunca yapılan bütün hitapları incelemekten ziyade bunların dikkat çekici olanlarının üzerinde duracağız.

Bunu yaparken bazı çevrelerce Muhammed (a.s.)'e aidiyetinden sakınılan bir takım hareketleri, onun bir peygamber ve her şeye rağmen bir beşer olması gibi iki olgu açısından objektif olarak değerlendireceğiz. Dolayısıyla çalışmamızda vakıaları olduğu gibi kabul ederek, Kur'ân-ı Kerim'in Hz. Peygamber'e olan seslenişini seçilmiş bir beşerin ve onun şahsında Dünya İnsanlık Ailesi'nin eğitimi noktasından ele alacağız.

Araştırmamızda ortaya çıkarmak istediğimiz hususlar şunlardır: Peygamber (a.s.)'e "ă̆ır bir söz olarak yükleneceğ $i$ " ifade edilen ${ }^{14}$ Kur'ân'da mevcut olan bu hitapların yeri nedir? Bir beşer hayatında basit gibi görünen bu hitapların konusu niçin İlâhî bir kayıtla bütün muhatapların bilgisine sunulmuştur? Kur'ân ayetleriyle $\mathrm{Hz}$. Peygamber'e ve Müslümanlara yöneltilen bu hitaplann ilk İslam Toplumu'nda meydana getirdiği etkiler

9. Peygamberler günah işlemezler; ancak ufak hata, ayak sürçmesi anlamına gelen "zelle" işleyebilirler. Zelle kelimesinin anlamı için bkz: Ebü'l-Fazl Cemaleddin Muhammed b. Mükerrem b. Manzûr, Lisânü'l-Arab, Mısır tsz., II. 1513.

10 .

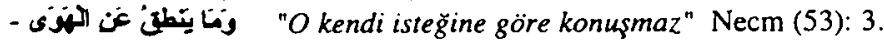

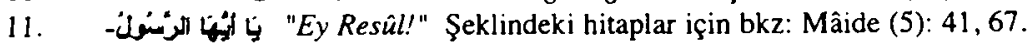

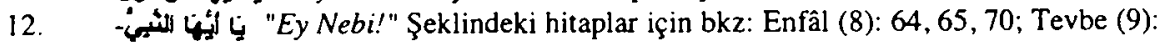
73; Ah7,âb (33): 1 - 28.

13. Peygamber (a.s.)'e zamirle yapılan bazı hitaplar için şu âyetlere bkz: Bakara (2): 119; Ra'd (13): 30; Fâtır (35): 24; Şûrâ (42): 48.

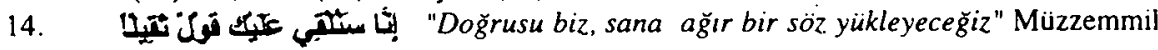
(73): 5 . 
nelerdir? Üzerinde duracağımız bir başka nokta ise Hz. Peygamber'in bazı düşünce ve davranışlarının sonunda vahyedilen hitapların içeriklerinin onun kendi şahsı ve yaşadığı tarih ile kayıtlı birer olgu olup olmadıklandır.

Araştırmamızın konusunu oluşturan ve Kur'ân'dan seçtiğimiz söz konusu hitaplar şunlardır: Emir, İkaz, Teselli, Hatırlatma, Tehdit, Tavsiye ve Bilgilendirme. Birinci makalemizde bunların ilk üçünü ikinci makalemizde ise diğerlerini inceleyeceğiz.

\section{A- Emir}

Cebrâil'in, Peygamber (a.s.)'e yönelttiği ilk hitabın 1آت "oku" emri olduğu, onun da buna cevaben " ما انا بتاري "Ben okuma bilmem" demesi

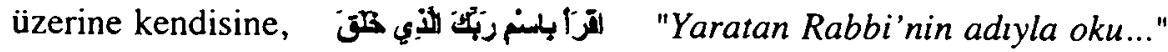
ibâreleriyle başlayan Alâk Sûresi'nin ilk beş âyetinin nâzil olduğu, İslâmî literatürde geniş bir kabul görmektedir. ${ }^{15}$

Muhammed (a.s.) için yeni bir dönemin başlangıcı olan Hira Mağarası'ndaki bu buluşma esnasında vahyedilen âyetlerin gerek muhtevalarında gerekse o esnada iki elçi arasında kurulan diyaloğun içeriğinde bize göre şu mesajlar bulunmaktadır:

1- Yüce Allah, okuma ve yazma bilmeyen bir insana toj "oku" emrini vermekle, ona daha önceden bilmediği birtakım şeyleri öğreteceğini bildirmiş, böylece onun daha önceden hiç alışık olmadığı bazı durumlara alı̧̧tırılacağı imâ edilmiştir.

2- Cebrâil'in yotirdiği "oku" emrine karşılık Peygamber (a.s.)' in "Ben okuma bilmem" diyerek aczini itiraf etmesi onun, Allah'ın emirleri karşısında herhangi bir tercihinin bulunmadığını gösterir. Aynı zamanda bu gerçek, vahyin peygamberin kendi uydurması olduğunu ileri sürenlerin iddialarını çürütmeye yönelik bir delildir.

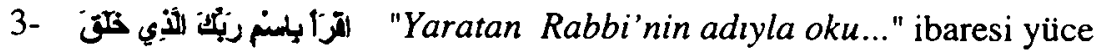
Allah'ın, seçtiği Elçi'ye sahip çıktığını, onu her yönüyle eğiteceğini ve mutlak bir gözetim altına alacağını ortaya koymaktadır. Bu sayede o,

15. Hira Mağarası'nda ilk vahyin inmesi ile ilgili olarak anlatılan haberler için bkz: Ebû Abdullah Muhammed b. Ismâîl Buhân, Câmiü's-sahîh, Istanbul 1401/1981, Bed'ü'lvahy 1 (1.3); Tefsîr (Alak) 1, (VI. 88); Ebü'l-Hüseyin Müslim b. el-Haccâc el-Kuşeyñ enNîsâbûn, Câmiï's-sahîh, İstanbul 1401/1981, Iman 73, (1.140); Ebû İsâ Muhammed b. Isâ et-Tirmîzî, Câmiü's-sahîh, İstanbul 1401/1981, Tefsîr (Müddesir) 71, (V.428); Ebû Ca'fer Muhammed b. Cerîr et-Taben̂, Câmï̈̈l-beyân an te'vîli âyi'l-Kur'ân, Beyrut 1408/1988, XXX.251; Ebü'l Hasan Ali b. Ahmed el-Vâhidî en-Nîsâbûn, Esbâbü'nnüzûl, thk: Kemal Besyûnî Zał̆lûl, Beyrut 1411/1991, s.14; Imâdüddin Ebư'l-Fidâ Ismail b. Ömer b. Kesîr, Tefsîrü'l-Kurâ'n'il-azìm, Beyrut 1412/1992, IV.564. 
kendisini eğiten Mutlak Güç adına yeryüzünde iş yapan ve kendiliğinden konuşmayan bir elçi olacaktır.

4- Hirâ Mağarası'nda olağanüstü bir durumla karşılaşan Muhammed (a.s.)'e yöneltilen "oku!" emri aslında ona verilen psikolojik bir destektir. Çünkü gördüğü manzara karşısında heyecanlanan, biraz da korkuya kapılan bir insana, sert olmayan böyle bir ifâde ile hitap edilmiş ve "Yaratan Rabb'inin adıyla oku" denmek suretiyle kendisinin bu türdeki hitaplara alıştırılacağı imâ edilmiştir.

Hz. Peygamber'e yapılan hitaplardaki bu emirler bâzen sâdece onun şahsına bazen de onun şahsında bütün muhataplara yöneltilmiştir. Ancak aşağıda da inceleyeceğimiz gibi sâdece onun şahsına yöneltilenlerden bile her devirdeki Kur'ân muhataplarının çıkarabileceği önemli mesajlar bulunmaktadır.

\section{1-Hz. Peygamber'in Şahsına Yönelik Emirler}

Büyük çoğunluğu risâlet görevi ile ilgili konularda yoğunlaşan bu hitapların en belirgin özellikleri; Peygamber (a.s.)'in durumuna ve o zamanki Müslümanları çevreleyen şartlara göre şekillenmeleridir. Müslümanların çok zay if ve müşriklerin tehditlerinin de zirvede olduğu bir dönemde gerçekleşen şu hitap bu çerçevede tipik bir ömektir:

(Ey Muhammed!) sana emr olunanı açıķ̧a söyle ve ortak koşanlardan yüz çevir."16 Müfessir et-Taben̂́ye göre bu áyette Nebi (a.s.)'ye, "Allah'a ortak koşanlarla savaşmaktan vazgeç" denilmektedir. Tabi ki bu emir cihadın farz kılınmasından önce idi.17 Incelediğimiz bu hitapta Hz. Peygamber âdeta uyarılarak, onun her şartta Kur'ân'ı tebliğ etmesi yani gerçeği tüm berraklığıyla ortaya koyması emredilmekte ${ }^{18}$ ve bunu engellemek isteyen müşriklere de aldırmaması 19 istenmektedir. Bu ibarede ön plana çıkarılan ve yerine getirilmesi emredilen en önemli olgu; vahyin her şeye rağmen tebliğ edilmesidir. Aynı ibarede müşriklere özellikle fiilî bir karşı çıkıştan bahsedilmemesi dikkate şayandır. Böylece Cenâb-ı Hak, Nebîsi'ne zayıf olduğu bir dönemde sâdece tebliğ vazifesini vererek, onu düşmanlanının

16. Hicr (15): 94 .

17. Câmiü'l-beyân, XIV. 69.

18. Bu âyette geçen مد "sa-de-a" kelimesi bir şeyi kesin ve net olarak açıklamak, ilan etmek anlamina gelmektedir. Bkz: Lisânü'l-Arab, Ill. 2414; Muhammed Murtaza ezZebîđî, Tâcü'l-arûs min cevâhîri'l-kâmûs, Beyrut tsz., V. 410.

19. Geniş bilgi için bkz: Ebû Abdullah Muhammed b. Ahmed el-Kurtubî, el-Câmi'li ahkâmi'l-Kur'ân, Kahire tsz., X. 61, 62; Tefsîrü'l-Kurâ'ni'l-azim. II.579. 
muhtemel saldırılarından korumuştur. Dolayısıyla savaş içermeyen bu emir, henüz olgunlaşma sürecindeki çekirdek İslâm cemaatinin güvenliği ve geleceği açısından çok isabetli bir müdahale olmuştur.

Zayıf ve güçsüz olduklan bir dönemde Müslümanlan İslâm dışı grupların baskılarına fiilî bir başkaldırıdan alıkoyan bu emir hitabı, $\mathrm{Hz}$. Peygamber'in şahsında bazı insanların içinde bulunduklan psikolojik durumlarımı göz önünde bulundurarak onları rahatlatıcı mesajlar da sunmaktadır. Uygun olmayan bir ortamda baskı ve zulme karşı koyarak savaşmayı çetin birer olgu olarak kabul eden ve bu sebeple Müslüman olmayı kendi hayal dünyalarındaki bir başka zamana bırakanların ortaya attıkları bahaneler bu hitapla izâle edilmiştir. Böylece Kur'ân, zor bir zamanda "zulme karşı fiilî bir direnişi" şartların uygun olacağı bir başka zamana tehir etmekle, bazı insanların daha erken Müslüman olmalarını sağlamıştır. Bu emir hitabı aynı zamanda yukarıdaki olgular sebebiyle tam bir teslimiyet içerisinde olmayan bazı zayıf imanlı Müslümanları da psikolojik olarak rahatlatmış ve inançlarında sabit kılmıştır.

Kur'ânî emirlerin ifasındaki durumsallığa güzel bir ömek oluşturan bu hitabının içeriğinde yukanda kendilerinden bahsettiğimiz gruplanın dışındaki inanırlara yönelik psikolojik bir mesaj da bulunmaktadır. Şöyle ki; inançlarının gereklerini tam olarak yerine getiren samimi mü'minlerin üzerinden ağır bir yük, uygun şartlann oluşmasına kadar kaldırılmış böylece onların İlâhî bir gözetim altında oldukları ihsas edilmiştir. Bu şekilde $\mathrm{Hz}$. Peygamber de, kendisine yönelebilecek birtakım yakınmalardan kurtulmuştur.

Vahyin daha sonraki yıllarında İslâm cemaatinin büyümesine ve kuvvetlenmesine paralel olarak Peygamber (a.s.)'e yöneltilen emir hitaplarının içeriklerinin de farklılaştığı görülmektedir:

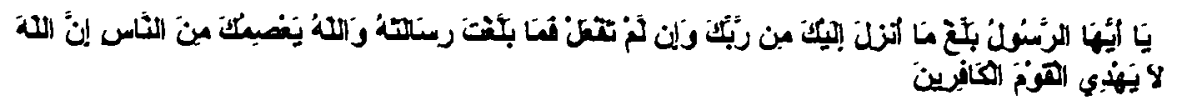

"Ey elçi! Rabb'inden sana indirileni bildir. Ĕ̆er (bunu) yapmazsan, O'nun mesajınt iletmemis olursun. Allah, seni insanlardan koruyacakttr. Allah, inkarcıları doğru yolu iletmez."20

Bu hitapta Peygamber (a.s.) için her yönden bir bağlayıcılık bulunmaktadır. Bir önceki hitaba benzer olarak burada da onun tebliğ görevini ifa etmesi istenmektedir; ancak bu ibârelerin son tarafında kendisine bahşedilen can güvenliği garantisi bu hususta güç ve kuvvet kullanılarak yapılacak bir mücadeleyi de öngörmektedir. Bu aynı zamanda onun tebliğ vazifesini ifâ 
ederken birtakım sıkıntılar ve endişeler içerisinde bulunduğunu da ortaya koymaktadır. Hatta bir rivâyete göre Nebi (a.s.), indirilen vahyin bir kısmını açıkça tebliğ ettiği halde, bir kısmını müşriklerin baskısı nedeniyle yapamamıştır. ${ }^{21}$ Böyle bir tehlike karşısında bazı sahâbilerin onun kapısında geceleyin nöbet tuttuklan da bilinmektedir. Bu gerçek, Hz. Aişe (ö: 58 / 678)'nin şu ifadeleriyle de teyit edilmektedir:

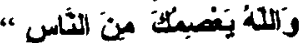

... Allah seni insanlardan koruyacaktır..." (Mâide /67) âyeti nâzil oluncaya kadar Nebi (a.s.)'nin yanında muhafız bulunuyordu. Bu âyet inince

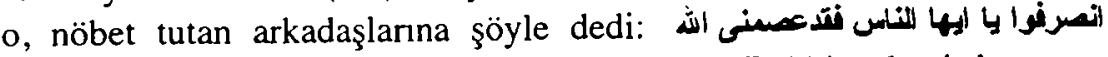
"Ey insanlar! Artık evlerinize gidin; çünkü Rabbim beni korumasına almıştır." 22

Peygamber (a.s.)'in tebliğ vazifesi esnasında karşılaştığı bu duruma yukandaki hitapla müdahale eden yüce Allah artık bu aşamadan sonra ona ihtiyaç duyduğu can güvenliği garantisini vererek, yaptığı tebliğe engel olan unsurları kuvvet kullanarak ortadan kaldırmasını kendisinden istemiş̧ir.

Bize göre yukarıdaki hitabın vermek istediği mesaj şudur:

Eğer Hz. Peygamber, kendisine bahşedilen bu imkanlardan sonra Kur'ân'dan tek bir âyeti bile gizleseydi o zaman vahyin tamamını gizlemiş, dolayısıyla elçilik görevini yapmamış olurdu. ${ }^{23}$ Bu konuya ikinci defa işaret eden bir başka âyetin bulunmayışı, vahyin tebliğinin sıhhatli ve gerektiği şekilde yapıldığının bir delilidir. Ayrıca Hz. Aişe'ye ait şu ifadeler de bu gerçeği konu edinmektedir: "Kim Muhammed'in Kur'ân'dan herhangi bir şeyi gizlediğini iddia ederse Allah'a iftira etmiş olur ${ }^{24}$ ve o yalancıdır."25 Eğer Allah Resûlü vahiyden bir şeyi gizleyecek olsaydı

"Allah'ın açı̆̆a vuracă̆ı şeyi içinde saklıyordun" (Ahzâb/37) âyetini gizlerdi.26

Aslında yukanda incelediğimiz hitap, hem $\mathrm{Hz}$. Peygamber'e hem de onun şahsında bütün Müslümanlara yöneltilen bir emir ihtiva etmekte ve

21. Geniş bilgi için bkz: Fahreddin Muhammed b. Ömer er-Râzî, Mefâtîhü'l-gayb, Beyrut tsz., XI. 48.

22. Bu olayla ilgili olarak bkz: Ebü'l-Kâsım Süleyman b. Ahmed et-Taberânî, el-Mu'cemü'lkebîr, thk: Hamdi Abdulmecid es-Selefĩ, byy. tsz., XI. 205; Nureddin Ali b. Ebû Bekr elHeysemî, Mecmeü'z-zevâid ve menbeü'l-fevâid, Beyrut 1402/1982, VII.17; Câmiü'lbeyân, VI.307,308, Esbâbü'n-nüzûl, s. 205; Celaleddin Abdurrahman b. Ebî Bekr esSüyûtî, Lübâbü'n-nükûl fi esbâbi'n-nüzûl, Beyrut tsz., s. 115

23. Bu konuda geniş bilgi için bkz: Câmiü'l-beyân, VI. 307.

24. Câmiü'l-beyân, VI. 309.

25. el-Câmi'li ahkâmi'l-Kur'ân, V. 243; Tefsîrü'l-Kur'âni'l-azîm, II. 80.

26. Mefâtîhül-gayb, XI. 49. 
vahyi tebliğle görevli olanların şartlar ne olursa olsun ondan hiçbir şeyi gizlememelerini istemektedir.

Diğer taraftan, inceleyeceğimiz şu âyette de olduğu gibi, Peygamber (a.s.)'in şahsına doğrudan yöneltilen emir şeklindeki hitaplardaki bağlayıcılık ve sınırlılık bazen çok belirgindir:

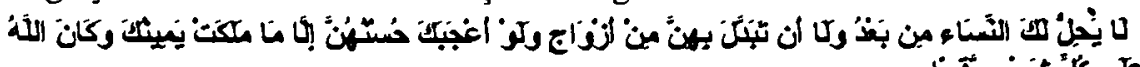

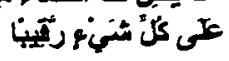

"(Ey Muhammed!) Bundan sonra artık sana (başka) kadınlar(la evlenmek), güzellikleri hoşuna giden kadınlar olsa da bunları başka eşlerle değisstirmek helâl değildir. Yalnız sahip olduğun cariyeler bunun dışındadır. Allah her şeyi gözetleyicidir."27

Bu hitap daha önce incelediğimiz Ahzâb Sûresi'nin 50. âyetinde söz konusu edilen kadınların dışındakilerle $\mathrm{Hz}$. Peygamber' in evlenemeyeceğini bildirerek bu hususta bir sınırlama getirmektedir. Ancak buradaki İlâhî bildirim her ne kadar Hz. Peygamber'in şahsına ait olsa bile bu âyeti çevreleyen sınırlılık içerisinde eşlerine de bir işaret bulunmaktadır; çünkü burada ifade edildiği üzere, hanımlarından bazıları ondan birtakım taleplerde bulunmuşlar o da bundan rahatsızlık duymuş̧u. Daha sonra Cenâb-1 Hak, vahiyle bu duruma müdahale etmiş ve peygamber eşlerinin ya dünya malını isteyip Allah Resûlü'nden boşanmalarını ya da dünya malına sırt çevirip Allah rızasına razı olmaları hususunda kendilerini bir tercih yapmayla baş başa bırakmıştı. ${ }^{28}$ Bize göre bu hitap ele aldığı konuya son noktayı koymuş ve bu hanımlara, Peygamber (a.s.)'in evlenebileceği başka kadınların da bulunduğunu bildirmiştir. Bu da hanımlarının dünyevî bir takım istekleri karşısında sıkıntı çeken Nebi (a.s.) için geniş bir açılım sağlamıştır. Bu gerçek vurgulanırken sözünü ettiğimiz hitapta Peygamber eşleri doğrudan muhatap alınmayarak onlara tarihsel bir göndermeyle yetinilmiştir. Diğer taraftan aynı ibarelerde bu seçkin hanımlanın öteki kadınlarla mukayese edilmemeleri, kendilerine verilen İlâhî taltifin bir göstergesidir.

Buraya kadar anlattıklarımızla, Hz. Peygamber'in şahsına doğrudan yapılan emir hitaplanına işaret etmiş bulunmaktayız. Şimdi de onun şahsında, ona ve mü'minlere yöneltilen emirleri ihtiva eden hitapları inceleyeceğiz.

27. Ahzâb (33): 52 .

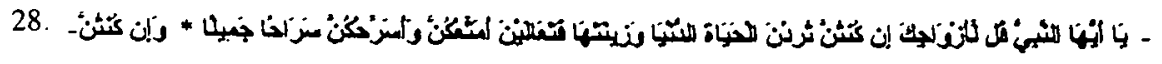

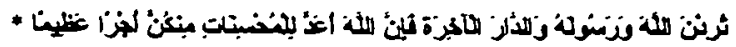

"Ey Peygamber! Eşlerine de ki: 'Eğer siz, dünya hayatını ve onun süsünü istiyorsanız gelin size boşanma bedeli vereyim ve sizi güzellikle salayım. Yok ĕger Allah'l ve ahiret yurdunu istiyorsanız biliniz. ki Allah, sizden güzel hareket edenlere büyük bir mükafaat hazırlamışı "ı" Ahzâb (33): 28, 29. 


\section{2-Hz. Peygamber'e ve O'nun Şahsinda İnananlara Yönelik Emirler}

Kur'ân vahyinin bir kısmı, İslâm toplumunda meydana gelen bazı olaylar sebebiyle hem $\mathrm{Hz}$. Peygamber'e hem de onun şahsında bütün Müslümanlara yönelik hitaplar şeklinde inzâl olunmuştur. Toplumda öteden beri süregelen yanlı̧ uygulamalara $\mathrm{Hz}$. Peygamber'den kesin çözüm getirmesi istendiğinde vahyin er veya geç çözüm getiren bir hitap ile mevcut duruma müdahalede bulunduğu bir gerçektir. Meselâ Enes b. Mâlik (ö: 93/712)'in rivâyet ettiği şu haber bu konudaki vakıalardan sâdece birisidir: "Hz. Ömer (ö: 23/644) bir gün Allah Resûlü'ne şöyle dedi: 'Ey Allah Resûlü, senin evine iyi insan da kötü insan da geliyor; bunun için hanımlarına örtünmelerini emredemez misin?"29 Onun bu dileğinden sonra $\mathrm{Hz}$. Peygamber'e yapılan şu İlâhî hitap hem ona ve hem de Müslümanlara bazı sorumluluklar yüklemiştir:

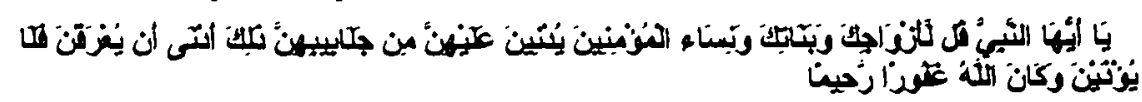

"Ey Peygamber! Hantmlarina, kızlarına ve mü'minlerin kadınlarına (bir ihtiyaç için dışarı çıktıkları zaman) örtülerini üstlerine almalarını (vücutlarını örtmelerini) söyle. Onların tanınmaması ve incitilmemesi için en elverişli olan budur. Allah, çok bağışlayan esirgeyendir." 30

Buradaki hitabın hemen arkasından gelen emirlerin kesin ve açı oluşu ilk etapta dikkat çekmektedir. Ayrıca öncelikli olarak Peygamber (a.s.)'in eşlerine ve kızlarına yöneltilen bu emirler, ilk tatbik edicilerinin kimler olması gerektiğinin tayini açısından da önemlidir. Bu vesile ile $\mathrm{Hz}$. Peygamber örtünnının usûlünü kendi hanımlarına ve kızlarına rahat bir şekilde göstermiştir. Bu hususta önceden beri devam eden yanlış gelenek değiştirilerek örtünme meselesi bütün ayrıntılarıyla onun tarafından açıklanmış ve Müslüman hanımların giyim tarzı yeni bir şekle kavuşturulmuştur.

Peygamber (a.s.)'e ve inananlara yöneltilen emir hitaplannın bir çoğunun konusunu aile ilişkileri oluşturmaktadır. Bir rivâyete göre Peygamber (a.s.), hanımı Hafsa (r.ha.)'yı hayızlı bir halde iken boşamış ve bu olaydan sonra şu âyet nâzil olmuştur:31

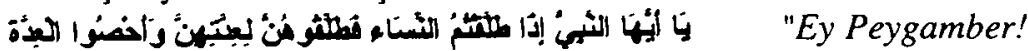

Kadınları boşamak istediğiniz zaman iddetleri içinde boşayın ve iddeti de sayın..."32

29. el-Buhârî: Tefsîr (Ahzâb) 33, (VI. 24).

30. Ahzâb (33): 59 .

31. Esbâbü̈n-nüzûl, s. 456; Mefâtîhü'l-gayb, XXX. 29; el-Câmi'li ahkâmi'l-Kur'ân, XVIII 148; Tefsîrü'l-Kur'âni'l-azîm, IV. 403.

32. Talak (65): 1 . 
Bu âyetteki hitap Allah Resûlü'ne yönelik olmasına rağmen boşama hakkına sahip olan herkesi bağlayıcıdır. ${ }^{33}$ Zaten bu husus hem âyetteki hitabın hemen arkasından gelen çoğul ifâdesi (Kadınları boşamak istediğiniz...)'nden hem de Peygamber (a.s.)'in Abdullah b. Ömer (ö:73/692) ile ilgili olarak yaptığı şu uygulamasından anlaşılmaktadır: Bu genç sahabi hayızlı olan hanımını boşamıştı. Hz. Ömer (ö:23/644) oğlunun bu yaptığını Nebi (a.s.)'ye haber verince, kendisi Abdullah (r.a.)'a çok kızmış ve ona şu haberi göndermiştir: "Abdullah'a söyleyin, hanımını tekrar alsın ve hayızlı durumu bitinceye kadar bırakmasın; eğer hâlâ onu boşamak isterse ona dokunmasın ve temiz olarak boşasın..."34 Tabiki bu emir aynı durumdaki bütün Müslümanlar için de geçerlidir.

İncelediğimiz bu âyetteki hitap ile bunu takip eden emirlerde bize göre önemli olan husus şudur: Ayetteki hitap Hz. Peygamber'e yöneltilmiştir ve ondan istenen şey hanımlarını hayızlı iken boşamamasıdır. Kur'ân, Peygamber (a.s.)'den bunu isterken muhataplarının sayısını, kullandığı ifadelerdeki çoğul eki ile genişletmiş ve aynı konumdaki bütün Müslümanları bu hususa dahil etmiştir. Böylece yüce Allah, risâlet gibi büyük bir görevi kendisine emanet ettiği Nebisi'ne, yapmaması gerek bir şeyi sâdece onu muhatap alarak söylememiş̧ir. Bu da ona verilen İlâhî değerin bir yansımasıdır. Zaten Peygamberlerin sert emirlere maruz kalmaları İlâhî irâdenin vahiy tarihinde sıkça başvurduğu yöntemlerden birisi değildir. Buna rağmen onların bu süreç içerisinde bazen İlâhî ikazlara maruz kaldıklan da bir gerçektir.

\section{B- Íkaz}

Peygamber (a.s.)'e yöneltilen hitaplar içerisinde en çok dikkat çekenler, içeriklerinde İlâhî birer ikaz taşıyanlardır. Bu ikazlar bazen sâdece Allah Resûlü'ne bazen de hem ona hem de onun şahsında bütün mü'minlere yöneltilmiştir. Kur'ân'ın tenzil süreci içerisinde bu ikazlara sebep olan olaylar incelendiğinde, onların ya gerçekleşmesi imkansız olan bir takım

33. Ebü'l-Kâsım Cârullâh Mahmud b. Ömer ez-Zemahşerî, el-Keşsâf an hakâiki't-tenzîl ve uyûni'l-ekâvîl fi vücûhi't-te'vîl, Beyrut tsz.. IV. 552; Mefâtîül-gayb, XXX. 29; Bedreddin Muhammed b. Abdullah ez-Zerkeşî el-Burhân fí ulûmi'l-Kur'ân, Beyrut tsz., II. 218; Celaleddin Abdurrahman b. Ebû Bekr es-Süyûtî, el-îtkân fi ulûmi'l-Kur'ân, İstanbul 1398/1978, II. 43.

34. Bu haberle ilgili olarak bkz: el-Buhâñ Talak 2, (VI.163); Müslim. Talak 2, (II.1093); Ebû Dâvûd Sülcyman b. el-Eş'âs es-Sicistânî, es-Sünen, İstanbul 1401/1981, Talak 4, (II.643); Ebû Abdullah Muhammed b. Yezid b. Mâce el-Kazvînî, es-Sünen, İstanbul 1401/1981, Talak 2, (1.651); Câmiii'l-beyân. XXVIII. 131; Esbâbü'n-nüzûl, s.457; Tefsîrül-Kur'âni'l-azîm. IV. 403. 
ısrarcı durumlardan -Mesela Hz. Peygamber'in, küfürlerinde inat edenlerin İslâm'a girmeleri hususundaki israrlı tutumu gibi- ya da Nebi (a.s.)'nin içinde bulunduğu şartlar dolayısıyla aldığı bir takım kararlardan kaynaklandığ $\breve{g}_{1}$ görülecektir. Meydana gelen bu olayların tekerrürü, yapılan ikazlarla önlenmiştir. Bunun yanı sıra Peygamber (a.s.)' in kalbinde yer ederek icrasına niyetlendiği ancak İlâhî irâde tarafından desteklenmeyen bazı hususlar da aşağıda inceleyeceğimiz söz konusu ikazlar vasıtasıyla daha uygulama safhasına geçilmeden engellenmiştir.

\section{1- Hz. Peygamber'in Şahsına Yönelik Ikazlar}

Bize göre bu tür ikazlarda üzerinde durulan en önemli husus, Peygamber (a.s.)'in İslâm dışı gruplara en küçük bir meylinin bile olamayacağıdır. Meselâ müşriklerin ona uzlaşma teklifleri yapmaları karşısında nâzil olan İlâhî hitap hem müşriklere gereken cevabı vermiş hem de bu türden konuları onlarla konuşmaması için Peygamber (a.s.)'i ikaz etmiştir. Bu bağlamdaki diğer ikazlar ise ya Allah Resûlü'nün ya da bazı sahâbilerin Müslüman olmayan akrabalarıyla devam ettirdikleri ilişkileri sebebiyle gerçekleşmiştir. $\mathrm{Bu}$ çeşit ikazlan fiilin gerçekleşmesinden önce ve fiilden sonra olmak üzere iki grupta inceleyeceğiz.

\section{a- Fiilden Önce İkaz}

Kibir ve gurur müşrik karakterinin en belirgin iki unsurudur. Onların bir kısmı imansızlıklan hususunda sığınacak bir bahaneleri kalınayınca toplumda kendi mevkilerinin yüksek olduğunu buna karşın mü'minlerin fakir ve zayıflardan oluştuğunu dolayısıyla bu insanlarla bir araya gelerek Müslüman oldukları zaman kendi değerlerinin kalmayacağını iddia etmişlerdir. Bununla da yetinmeyen müşrikler, Peygamber (a.s.)' den hoşlanmadıkları bu insanları yanından uzaklaştırmasını istemişlerdi. Hz. Peygamber'in yanına gelen bu düşüncedeki bir grup müşrik, aralarında Sad b. Ebi Vakkas (ö: 50/670)'ın da bulunduğu altı sahabeyi oracıkta görünce öfkelenerek onların dışarı çıkarılmalarını istemişlerdi. Bir ara Peygamber (a.s.)' in kalbinde müşriklerin bu isteklerini kabule yönelik bazı düşünceler hasıl olmuşsa da, o daha bir karara varmadan nâzil olan şu hitap ile, bu türden isteklere asla boyun eğmemesi için ikaz edilmiştir: 35

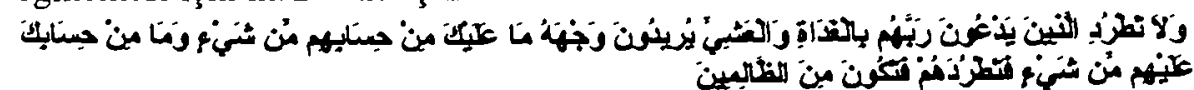

35. Bu konunun farklı ifadelerle anlatımı için bkz: Müslim, Fedâilü's-sahâbe 5, (II.1876); Ibn Mâce, Zühd 7, (II.1383); Esbâbü'n-nüzûl, s. 219; Mefâtihü'l-gayb, XII. 234; elCâmi'li ahkâmi'l-Kur'ân, VI 431; Tefsîrü'l-Kur'âni'l-azîm, II. 139; Lübâbü'n-nükûl, s. 123 . 
"(Ey Muhammed!) Sabah, akşam hoşnutluğunu isteyerek Rabb'lerine yalvaranları kovma! Onları hesaba çekmek sana, seni hesaba çekmek de onlara düşmez $k i$, onları kovarak haksızlık edenlerden olasın." 36

Peygamber (a.s.)'i yanlış bir iş yapmaktan engelleyen bu ikazda istenen en önemli şey; onun İslâm dişı gruplar tarafından öne sürülen ancak İlâhî irâdenin onaylamadığ döneminde müşrikler tarafından ileri sürülen ve Allah'tan başka ilahların varlığını tanıma temeline dayalı olarak yapılan bu uzlaşma tekliflerij ${ }^{37}$ Peygamber (a.s.)'in söz konusu teklif sahiplerine cevap vermesine firsat bırakmadan Kur'ân tarafından reddedilmiş ${ }^{38}$ ve bu konuda tek söz sahibinin Allah (c.c.) olduğu vurgulanmış, ayrıca onun bu konuyu gündeme getiren müşriklerle diyaloğunu sürdürmesine de İlâhî bir hitap ile müdahale edilmiştir. Kanaatimizce Cenâb-ı Hak, bu ikaz ile ona şu mesajı vermek istemiştir: "Ey Resûlüm! Eğer sen, müşriklerle diyaloğunu sürdürmek istiyorsan niyetlerinin iyi olmadığını onlara bildir ve kendilerine şöyle söyle: 'Ey kâfirler! Ben sizin ilahlarınıza ibadet etmem. Siz de benim Rabb'ime ibadet etmezsiniz. O halde boşuna çaba sarf etmeyin."

Nebi (a.s.)'ye isteklerini kabul ettirmekten ümitlerini kesmelerinden sonra yeni bir taktik geliştiren müşriklerin hiç olmazsa onun, kendi ilahlarına saygı duymasını sağlamaya çalıştıklanını görüyoruz. Şu olay bu hususta bariz bir örnektir: Aralannda Ebû Süfyan b. Harb'ın da bulunduğu bir grup müşrik, Peygamber (a.s.)'e şu teklifi yapmışlardı: "Eğer ilahlarımız olan Lat, Uzza ve Menat'ı kötülemekten vazgeçer ve onlarnn kendilerine tapan kimselere şefaatçi olacaklarını söylersen, biz de seni, Rabb'inle baş başa bırakınz." Şirk temeline dayalı uzlaşma banilerinin bu sözleri $\mathrm{Hz}$. Peygamber'e çok ağır gelmişti. Orada bulunan Hz. Ömer (ö:23/644)' in 'Ey Allah Resûlü! İzin ver de şunlan hemen cezalandırayım' şeklindeki sert çıkışını, Nebi (a.s.): "Hayır olmaz! Ben onlara eman verdim" diyerek tasvip etmemiştir. Bu olaydan sonra yüce Allah, Resûlü'nü şu hitap ile ikaz etmiştir: ${ }^{39}$

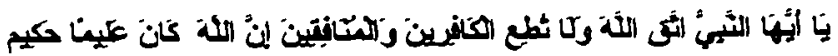

36. En'âm (6): 52 .

37. Müşrikler tarafından Peygamber (a.s.)'e yapılan bu uzlaşma teklifi için bkz: Esbâbü'nnüzûl, s. 496.

38. Bkz: Kâfinûn Sûresi:

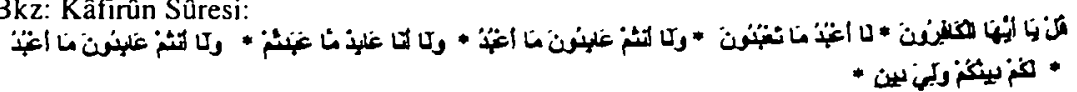

"Ey Muhammed! De ki: 'Ey inkarcılar! Ben sizin yaptığınz ibâdeti yapmam. Siz de benim yaptığım ibâdeti yapmazsınız. Ben asla sizin yapmı̧ olduğunuz ibâdeti yapıcı değilim. Siz de benim yapmakta olduğum ibâdeti yapıcı değilsiniz. Sizin dininiz size, benim dinim banadır."

39. Esbâbü'n-nüzûl, s. 364; el-Câmi'li ahkâmi'l-Kur'ân, XIV. 114; Lübâbü'n-nükûl. s. 229. 
"Ey Peygamber! Allah'tan kork, kâfir ve münâfiklara itaat etme. Elbette Allah, her şeyi bilen ve yerli yerinde yapandır."40

$\mathrm{Bu}$ ikazı, Hz. Peygamber'in müşrikler tarafından yapılan uzlaşma teklifine sıcak bakması veya onlara meyletmesi gibi hususlar gerekli kılmamıştır. Zaten böyle bir şey de gerçekleşmemiştir. Bize göre bu ikazın nedeni; Peygamber (a.s.)'in kendisine bu hususta bir teklif getiren müşriklere eman vermesi ve onları muhatap almasıdır. Hz. Pcygamber'in yaptığı sâdece budur; ancak tevhid konusu çok ciddî bir mesele olduğu için yüce Allah, bu ilkenin aleyhinde yanlış anlamaya neden olabilecek hiçbir düşünce ve harekete izin vermediğini göstermek için bu mesajını İlâhî kayıtla inananlara duyurmuştur.

Hz. Peygamber, İslâm'ı kabul etmeden ölen amcası Ebû Tâlib'in hakkındaki sözleri sebebiyle de İlâhî hitap ile ikaz edilmiştir. Onun, amcasını kastederek: "Yasaklanmadığım sürece senin için istiğfarda bulunacağım" demesi üzerine nâzil olan şu âyet, kendisini, yapmayı tasarladığı bu eylemden vazgeçirmiştir:41

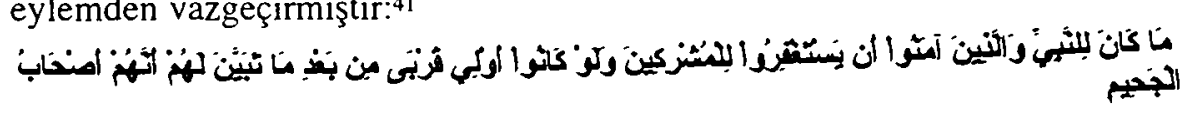

"Akrabâ bile olsalar, cehennemliklerden oldukları açığa çıktıktan sonra (Allah'a) ortak koşanlar için mağfiret dilemek ne Peygamber'in ne de inananların yapacağı bir iştir."42

Şu iki hususun bu hitapta özellikle teyit edildiğini görmekteyiz: Bunlardan biriariși, kan ve akraba bağının iman bağından asla üstün olmadığı gerçeğidir. İkincisi ise, Ebû Tâlib örneğinde olduğu gibi kişi inanmadığı sürece bu dünyada yaptığı iyiliklerin dünyada kalacağı ve bunlann ahirette kendisine asla fayda vermeyeceğidir.

Yukarıda incelediğimiz olayın bir benzeri sebebiyle de Peygamber (a.s.) yine İlâhî hitâba ve arkasından gelen ikaza muhatap olmuştur. Bununla ilgili olarak anlatılan olay kısaca şöyledir: "Münâfıkların ileri gelenlerinden Abdullah b. Selül öldüğü zaman oğlu, Allah Resûlü'ne gelerek babasını kefenlemek için gömleğini vermesini daha sonra da cenaze namazını kıldırmasını istemişti. O da gömleğini vermiş ve namaz için de hazırlanmıştı. Ancak bu olup bitenleri gören Hz. Ömer, kendisine: 'Ey Allah Resûlü!

40. Ahzâb (33): 1 .

41. el-Buhâñ: Tefsîr (Tevbe) 16, (V. 208); Müslim: Iman 9, (I. 54); Ebû Abdurrahman Ahmed b. Şuayb en-Nesâî, es-Sünen, Istanbul 1401/1981, Cenâiz 102 (IV.90); Esbâbư'nnüzûl, s. 266, 267; el-Câmi'li ahkâmi'l-Kur'ân. VIII. 272; Tefsîrü'l-Kur'âni'l-azîm. II. 407.

42. Tevbe (9): 113 . 
Rabbim, seni münâfıkların namazlarını kıldırmaktan yasaklamamış mıydı?' diye sorunca o: 'Rabbim beni bu konuda serbest biraktı' dedi. Peygamber (a.s.)'in bu sözlerinden sonra yüce Allah ona şu hitabını yöneltmiş ${ }^{43}$ ve kendisini bu konuda ikaz etmiştir:

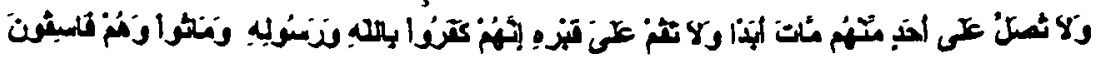

"Ve onlardan ölen birine asla namaz kllma, onun kabri başında durma. Çünkü onlar, Allah'ı ve Resûlü'nü tanımadılar, yoldan fıkmıs olarak öldüler."44

Bu hitabın içeriğindeki ikaz her zaman geçerlidir. ${ }^{45}$

Kendisine yöneltilen bu hitaplardan sonra Allah Resûlü, yapmaya niyetlendiği birtakım işlerden vazgeçmiştir; ancak bu bağlamdaki ikazlardan bir kısmı, Hz. Peygamber harekete geçtikten yani fiili işledikten sonra gerçekleşmiştir.

\section{b- Fülin Tekrannı Önlemeye Yönelik İkaz}

Burada inceleyeceğimiz ikazlar, fiilden sonra yapılmış olanlardır. Bütün yönleriyle iflas etmiş, bireysel ve toplumsal anlamdaki değerlerini kaybetmiş insan yığınlarından yeni ve ideal bir toplum oluşturmak isteyen bir peygamberin kendisini çevreleyen çok zor şartlar altında görev yaparken bütün muhataplarını memnun etmesi beklenemezdi. Mevcut olan zorluk onun alacağ (c.c.)' 'n desteğine ve korumasına mazhar olsa bile birtakım sürçmelerden de berî değildir. Zaten bunun aksini iddia etmek de onun beşer oluşuyla örtuişmezdi. Diğer bir deyişle; bir peygamberden bu bağlamda meydana gelebilecek bazı eylemler, her şeye rağmen onun beşer oluşunun birer teyididir. Seçilmiş kullarının, bu türden yeryüzü tasarruflarına müsaade eden Cenâb-ı Hak, onlan insan kimliğinden soyutlayan hatta daha da ileri giderek ilahlaştranlara da bir mesaj vermek istemiştir. Öyleyse bir peygamber, insanî özelliklerinden hiçbir zaman soyutlanmamıştır. O da diğer kullar gibi yemek yer, çarşı ve pazarda gezer belki de herkesin aynı anda kendisiyle muhatap olmasına tahammül edemeyebilirdi ama her şeye rağmen o bir tebliğciydi.

43. Bu haber hakkında değişik ifâdelerle bkz: el-Buhâñ, Tefsîr (Tevbe) 2, (V. 206); Müslim, Fedâilü's-Sahâbe 2, (V. 1865); et-Tirmîzî, Tefsîr (Tevbe) 10, (V. 279); en-Nesâi, Cenâiz 40, (IV. 37); el-Câmi'li ahkâmi'l-Kur'ân. VIII. 218; Mefâtîü̈l-gayb, XVI. 152; Tefsîrü'l-Kur'âni'l-azîm, II. 392, 393.

44. Tevbe (9): 84.

45. Bu konuda, geniş bilgi için bkz: Tefsîrül-Kur'âni'l-azîm, II. 392; Ebù'l-A'lâ elMevdûdî, Tefhîmü'l-Kur'ân-Kur'ân'ın Anlamı ve Tefsîri, trc: Komisyon, Istanbul 1996, II. 258. 
Bütün peygamberlet gibi $\mathrm{Hz}$. Muhammed de kendi dâvetinin güçlü olmasını ve geniş kitlelerce kabul edilmesini istemiştir. İşte bu bağlamda bir gün Mekke'nin ileri gelen müşrikleriyle konuşurken yanlarına izinsiz olarak gelen İbn Ümmü Mektum isimli bir âmâ: "Ey Allah Resûlü, Rabb'inin sana öğrettikleriyle beni irşad eder misin?" şeklindeki isteğiyle sözünü kesmişti. $\mathrm{Hz}$. Peygamber, bu insanla o anda ilgilenememiş ve müşriklerle yaptığı konuşmasını sürdürmüştü. Ancak bu olaydan sonra şu ikazların yer aldığı İlâhî hitaba muhatap olmuştur:46

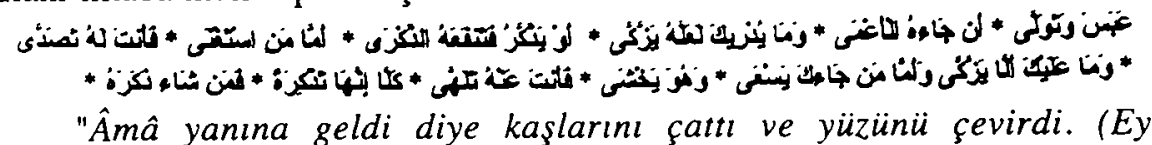
Muhammed!) Ne bilirsin belki de o arınacak, yahut öğüt alacak da bu öğ̈̈t kendisine yarayacak. Ama sen, kendisini yeterli gören kimseyi karşına aliyorsun. Onun arınmasından sana ne! (Allah'tan) korkup koşarak sana gelen kimseye ise aldirmiyorsun. Dikkat et! Bu bir hattrlatmadır. Dileyen ondan öğü alır." ${ }^{47}$

Müfessir ez-Zemahşen̂ bu hitap ile ilgili şu yorumu yapmaktadır: "Bu sûrenin başında, İbn Ümmü Mektum'un Peygamber (a.s.)'in meclisine gelmesi haber cümlesiyle verildikten sonra hitabın tekrar ona dönmesi, buradaki ikazın boyutlarının geniş olduğunu gösterir. Bu bir insanın bir başka insanı yanındakilere şikâyet etmesine benzer. Daha sonra bu kişi suçu işleyene döner ve onu azarlar." 48

Böyle bir hitapla Peygamber (a.s.)'in ikaz edilmesi hususunda şöyle bir yorum da yapılmıştır: "İbn Ümmü Mektum âmâ olduğu için şefkate ve ilgiye daha çok muhtaçtır. Kendisi Peygamber (a.s.)'in meclisinde konuşanlan görmediği için onun sözünü bilmeden kesmiştir." 49

Bütün bu anlatılanların tam aksine yukarıda incelediğimiz Abese Sûresi'ndeki hitabın Muhammed (a.s.)'e yapılmadığını aksine buradaki hitabın hakkı ve doğruyu görmeyen kâfirlere yöneltildiğini savunan görüşler de bulunmaktadır. 50

46. Bkz: et-Tirmîzî: Tefsîr (Abese) 80, (V. 432); Câmiü'l-beyân, XXX. 51; Esbâbü'n-nüzûl, s. 471; Mefâtîhü'l-gayb, XXX. 54; el-Câmi'li ahkâmi'l-Kur'ân, XIX. 211; Kadı Nâsıruddîn Ebû Saîd Abdullah b. Ömer el-Beydâvî: Envârü't-tenzîl ve esrârï't-te'vîl, Beyrut tsz., V. 173; Tefsîrü'l-Kur'âni'l-azîm, IV. 501; Lübâbü'n-nükûl, s. 324.

47. Abese (80): $1-12$

48. el-Keşâaf, IV. 701

49. Envârü't-tenzîl, V. 173

50. Bu konuda örnek olarak bkz: Ahmed et-Tâcî, Vahyu's-sîre, Mısır 1401/198I, s. 223-240. 
Bazılan ise bu hitabın bulunduğu sûreyi bir bütün olarak ele almakta dolayısıyla bu sûrenin hedefinin Mekke'nin ileri gelen kâfirleri olduğunu ifade etmektedirler. ${ }^{51}$

Bize göre bu bağlamda ileri sürülen görüşler iyi niyetli insanların Peygamber (a.s.)'i savunmaya yönelik çabalandır. Halbuki onun savunulmaya ihtiyacı yoktur. Zaten bu tür beşen̂ tasarruflar onun peygamberliğine de bir zarar vermez. Ayrıca o bu türden bir ikaz aldığını kendisi de kabul etmiş ve bu sebeple Ibn Ümmü Mektum'a saygı göstererek kendisine şöyle demiştir: " مرحبا بهن عاتبنى فيه ريى" "Merhaba, ey, Rabb'imin kendisiyle beni ikaz ettiği kişi!"s2

Eğer biz, Peygamber (a.s.)' in her zaman beşen̂ özelliklere sahip bir kul olduğunu kabul eder ve onu olağan konumundan çıkarmazsak, bu türden olayların sebeplerini daha iyi anlayabiliriz. Kendisine sohbet anında âmâ bir insanın gelerek soru sorması bir takdir-i Ilâhîdir. Yukanıda incelediğimiz hitap ile kanaatimizce Cenâb-ı Hak şöyle demek istemiştir: "Ey Resûlüm! Sen, Allah hakkında tartışan ve O'na şirk koşan, iman etmemekte direnen dolayısıyla doğruyu ve hakkı bir türlü görmek istemeyen şu müşriklerle irtibatını kes! Onların gözlerinde perde vardır ve onlar gerçekten kördürler! Ama fiziksel olarak gözleri görmeyen şu kulum (İbn Ửmmü Mektum)'un, kalp gözü açıktır. O halde sen, doğruyu görmeyen körlerle değil bununla ilgilen!"

Diğer taraftan bu hitabın Peygamber (a.s.)'e bildirmek istediği hususun

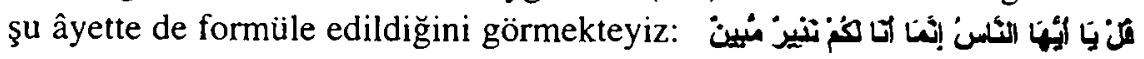

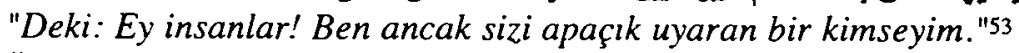

Öyleyse bir peygamberin, inanmayan insanlara yapacağı şey; sâdece tebliğ etmektir. Bununla ilgili olarak Peygamber (a.s.)'e yöneltilen hitaplardan birisinde de yine onun şöylece ikaz edildiğini görmekteyiz:

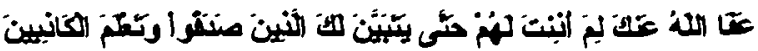

"Hay, Allah seni affetsin. Doğru söyleyenler sana iyice belli olup yalancılar bilinceye kadar onlara niçin izin verdin?"54

$\mathrm{Bu}$ hitaba konu edilenler, Tebük Savaşı'na katılmamak için asılsız mâzeretler uyduran münâfıklardır. ${ }^{55}$ Peygamber (a.s.), bu tavırlan karşıııında onlardan yüz çevirmiş ve istedikleri savaşa katılmama iznini de kendilerine

51. Tefhîmü'l-Kur'ân, VII. 36.

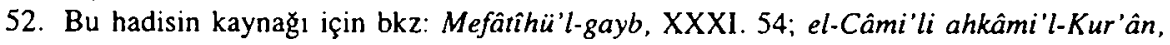
XIX. 213

53. Hac (22): 49.

54. Tevbe (9): 43 .

55. Câmiül-beyân, X. 142. 
vermiştir. Ancak bu gelişmeden sonra aralarında yukarıda incelediğimiz ikaz hitabının da bulunduğu bir grup âyet nâzil olmuştur. ${ }^{56}$ Dolayısıyla yüce Allah, savaşa gitmek istemeyenlerin bahanelerini kerhen de olsa kabul ettiğinden dolayı Nebisi'nin tabiatında var olan yumuşaklığı tasvip etmemiştir. Eğer onlar kendilerine izin verilmediği halde savaştan geri kalsalardı o zaman kendilerinin mü'min oldukları yolundaki iddialarının da yalan olduğu ortaya çıkacaktı. ${ }^{57}$

Daha önce incelediğimiz Abese Sûresi'ndeki hitapta yer almayan şu hususun bu hitapta bir ayrıntı olarak belirtildiğini görmekteyiz: Bu âyetin baş tarafında bulunan; "Hay, Allah seni affetsin" şeklindeki ibâre, Peygamber (a.s.)'in şanını yüceltmektedir. ${ }^{58} \mathrm{Bu}$ ayrıntı tıpkı bir adamın kendisi için çok kıymetli olan bir başka adama, yaptı̆̆ 1 bir işten dolayı, "Hayy, Allah seni affetsin sen benim şu işimi nasıl yaptın? Allah senden razı olsun, sen benim hakkımda ne düşüüüorsun?" gibi sözler söylemesine benzer.59 Dolayısıyla bu hitaba konu edilen, savaştan geri kalmak için asılsız mâzeretler ileri süren yalancılara izin verme ameliyesi, her ne kadar başlangıçta İlâhî irâde tarafından tasvip edilmemiş bir olay olsa da daha sonra bu husus Nebi (a.s.) tarafından irtikap edilen bir kabahat olmaktan çıkarılmıştır. Öyleyse bu hitabın Peygamber (a.s.)'e yöneltilmesindeki gaye nedir? Kanaatimizce bu ve daha önce incelediğimiz Abese Sûresi'ndeki hitabın en önemli gayesi; bunlara konu edilen olayların Nebi (a.s.) ve mü'minler tarafından bir daha tekrar edilmemelerini sağlamaktadır. Zaten aşağıda da inceleyeceğimiz üzere Kur'ân'daki hitapların bazılarında Hz. Peygamber' in yanı sıra mü'minlere de birtakım ikazlar yapılmaktadır.

\section{2- Hz. Peygamber'e ve O'nun Şahsında İnananlara Yönelik İkazlar}

Bu kısımda konumuzla ilgili olan iki önemli ikaz hitabını inceleyeceğiz. Bunlardan ilki Bedir Savaşı'ndaki esirlerin durumu ile ilgilidir. Bu savaş, Müslümanların kesin zaferi ile sonuçlandıktan sonra müşriklerden esir edilenler, Peygamber (a.s.)'in huzuruna getirilmişler o da bu esirlere yapacağı işlemi arkadaşlarıyla istişâre etmişti. Orada bulunanlardan Hz. Ebû Bekr (ö: 13/634): "Ey Allah Resûlü, bu esirler senin akrabalarındır, onları serbest bırak" diye bir teklif yaparken Hz. Ömer (ö:23/644) onun bu teklifine karşı çıkarak şöyle demiştir: "Hayır ey Allah Resûlü! Onlar sana inanmadılar

56. Esbâbü'n-nüzûl, s. 252; İzzeddin Ebü'l-Hasan Ali b. Muhammed b. Esîr, el-Kâmil fí'tTârih, Beyrut 1399/1979, II. 277; Lübâbü'n-nükûl, s. 147.

57. Bkz: Tefhîmü'l-Kur'ân, I. 232.

58. Geniş bilgi için bkz: el-Câmi'li ahkâmi'l-Kur'ân, VIII. 154, 155

59. Mefâtihü̈l-gayb, XVI. 73. 
ve seni memleketinden çıkardılar ceza olarak onların boyunlarını vur!" Bu konuşmalardan sonra alınan karar gereği esirler fidye karşılığında serbest bırakılmışlardı. Ancak alınan karar ve akabinde gelinen bu nokta İlâhî irâde tarafından tasvip edilmemiş dolayısıyla hem $\mathrm{Hz}$. Peygamber hem de diğer Müslümanlar bu tasarruflan sebebiyle şu ikaz hitabına muhatap olmuşlardı:60

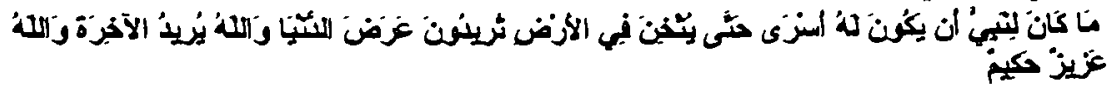

"Düşmanı ă̆ır yenilgiye uğratmadan esir almak hiçbir peygambere yaraşmaz. Siz geçici dünya malını istiyorsunuz. Oysa Allah, ahireti kazanmanızı istiyor. Allah yücedir, bilgedir. "61

Başlangıçta Peygamber (a.s.)'e yöneltilen bu hitap daha sonra gelen: "Siz geçici dünya malınt istiyorsunuz..." ifâdeleriyle diğer Müslümanlan da kapsayan bir şekle bürünmüştür; çünkü $\mathrm{Hz}$. Peygamber bu kararı yukanda da ifâde ettiğimiz üzere arkadaşlarıyla yapmış olduğu istişâreden sonra almıştır.

Bize göre bu ikazın, Peygamber (a.s.)'e ve Müslümanlara birlikte yöneltilmesinde esirler hakkında göruişünü belirten $\mathrm{Hz}$. Ebû Bekr' in yukarıda değindiğimiz şu sözleriyle irtibatlı olan önemli bir yönü de bulunmaktadır: "Ey Allah Resûlü, bu esirler senin akrabalarındır..." Peygamber (a.s.)'in, çok sevdiği arkadaşının bu sözlerine verdiği cevabı bilmiyoruz; ancak onun elinde esir olarak bulunan müşrik akrabaları hakkında belki ileride İslâm'ı kabul edebilirler ümidiyle böyle bir yol takip etmesi de mümkündür. $\mathrm{Bu}$ türden kaçınılmaz insanî duyguların ve ümitlerin sonucunda gerçekleşen bu ikazın yaptığı ilk çağrışım, her ne kadar zayıf oldukları bir dönemde Müslümanların esir ve mülk edinmelerinin doğru olmadığına yönelik olsa bile bir yönüyle de söz konusu esirlerin bırakılma sebep ve şeklinin tasvip edilmediğine imâda bulunmaktadır. Çok çağrı̧ımlı olduğuna inandığımız bu ikazın vermek istediği mesajlardan birisi de şudur: "İslâm davası Müslüman olmayan akrabaların durumuna göre şekillenemez; dolayısıyla evrensel İlâhî ilkelerinin uygulayıcısı ve temsilcisi olan Peygamber (a.s.)'e ve onun takipçilerine İslâm dışı faktörlerin -meselâ kan bağının- belirleyiciliğinde karar vermek ve hareket etmek uygun olmaz."

60. Esbâbü'n-nüzûl, s.243. Bedir Savaşı'nda Müslümanlar tarafından ele geçirilen esirlere yapılan işlem hakkındaki haberler için ayrıca bkz: Ebû Abdullah Muhammed b. Ahmed b. Hanbel eş-Şeybânî. el-Müsned, Beyrut tsz., I. 383; Câmiü'l-beyân, X. 44; Ebû Abdullah Muhammed b. Abdullah el-Hâkim en-Nîsâbûn, el-Müstedrek ale's-Sahîheyn, thk: Mustafa Abdulkadir Atâ, Beyrut 1411/1490; II. 359; Mefâtihhï'l-gayb, XV. 197; elCâmi'li ahkâmi'l-Kur'ân, VIII. 46; Mecmeü'z-zevâid, VI. 86; Tefsîrü'l-Kur'âni'l-azîm, II. 338; Lübâbü'n-nükûl, s. 141.

61. Enfâl (8): 67 
Zikrettiğimiz bu husus evrensellik iddiasındaki bütün sistemlerin vazgeçemeyeceği bir asıldır. Aksi takdirde kabile ve akraba tutuculuğuna uygun hale getirilen prensiplerin geniş kitlelerce kabul görmeleri beklenemez.

Burada inceleyeceğimiz ikinci ikaz hitabı yine Peygamber (a.s.)'e ve ona yanlış karar verdirmeye çalışan bazı Müslümanlara yöneltilmiştir:

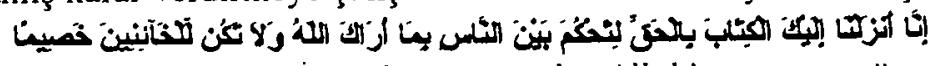

"(Ey Muhammed!) Insanlar arasında Allah'ın sana gösterdiği ile hükmetmen için Kitâb'ı sana hak olarak indirdik; (öyleyse) hainlerin savunucusu olma!"62

Aralarında bu ikaz içerikli cümlelerin de bulunduğu bir grup âyetin inişine sebep olan bu olay, Ensar'dan olduğu söylenen Ta'me b. Ubeyrik adındaki şahsın, çaldığı bir zırh ile ilgilidir. Kendisi söz konusu zırhı çaldıktan sonra Yahudi olan bir komşusuna emanet olarak bırakmıştı. Ancak bu zırh daha sonra emanet bırakılan Yahudi'nin yanında görülüp bunu çalanın Ta'me olduğu anlaşılınca onun bazı arkadaşları bunu kabullenmek istememişlerdi. Bununla da kalmayarak Hz. Peygamber'i de aynı şekilde inandırmak istemişler ve bunda bir süre de başarlı olmuşlardı. Ancak daha sonra inen yukarıdaki âyet ile $\mathrm{Hz}$. Peygamber ve ona yanlış bilgi veren Müslümanlar İlâhî ikaza mâruz kalmışlardı. ${ }^{63}$

Burada şu hususu da hemen belirtelim ki Allah Resûlü bu olayla ilgili henüz bir karara varmadan bu ikaz kendisine yöneltilmiş ve hata yapması önlenmiştir. ${ }^{64}$

Kur'ân-1 Kerim'in tenzil sürecinde önemli bir yer tutan ikaz, doğru karar vermenin zor ve önemli bir iş olduğunu vurgulamaktadır. Öyleyse inançlar bir şeyin peşinen kabul veya reddine yol açmamalı ve adâlete gölge düşürmemelidir. Çünkü adâlet olgusu, İslâm'ın üzerinde en çok durduğu vazgeçilmez unsurlardan birisidir.

İlâhî irâdenin bu ikaz ile hem Peygamber (a.s.)'e hem de Müslümanlara vermek istediği diğer mesajlar da kanaatimizce şunlardır:

1 - Yüce Allah'ın gözetiminde ve korumasında olan Peygamber (a.s.)'in çevresine çeşitli amaçlarla yerleşen bir takım insanlar bazı telkinlerle ona bir başkasının -ki bu kişi gayrimüslim bile olsa- aleyhine herhangi bir karar verdiremezler. Yüce Allah, Peygamberi'nin bu gibi önemli konularda yanılmasına müsaade etmemiştir.

62. Nisâ (4): 105 .

63. Kısaca bkz: el-Tirmîzî, Tefsîr (Nisâ) 4,(V. 244, 245); Câmiü'l-beyân. V. 267; Esbâbü'nnüzûl, s. 183; el-Keşsâf, I. 561; Mefâtîhü'l-gayb, XI. 32; Tefhîmü'l-Kur'ân. I. 403.

64. Câmiü'l-beyân, V. 265. 
2 - Peygamber (a.s.) çevresindeki insanlara ve bir takım çıkarlan için çeşitli yollarla kendisine ulaşıp etkilemeye çalışanlara dikkat etmeli ve onların telkinlerinin etkisinde kalmamalıdır. Kendisine ulaşamayan insanları da dinlemeli, vereceği kararlarda aceleci davranmamalı ve delilleri incelemelidir.

Üzerinde durduğumuz bu husus her zaman büyük önem taşımıştır. Her kademedeki idareciler için gerekli olan bu olgu ne yazık ki zaman zaman ihmal edilmiştir. Öyle ki idareciliğinde başarılı olan ve dürüst davranan nice kıymetli insanlar çoğunlukla kendilerini hiç yalnız bırakmayan (!) kötü niyetli insanların telkinlerinden fazlasıyla etkilenmişlerdir.

3 - Peygamber (a.s.) bakışlarını kendi müntesiplerine çevirmeli ve onların zaaflanın giderici tedbirler almalıdır.

4 - Müslüman olduğunu iddia eden herkesin söylediği ve yaptığı her şeyin doğru olmayabileceği ihtimali ile, İslâm dışı unsurlardan doğru sözlü kişilerin olabileceği gerçeğinin hiçbir zaman göz ardı edilmemesi gerekir. Öyleyse inanç meselesi bir şeylerin ön yargılı olarak kabul veya reddine yol açmamalı, âdaletin sağlanmasına gölge düşürmemelidir.

\section{C - Teselli}

Risâlet hayatı boyunca Peygamber (a.s.)'in başta İslâm dışı grupların menfî hareketleri olmak üzere bazı sebeplerden kaynaklanan bir takım sıkıntılara ve üzücü olaylara maruz kaldığı tarihî bir gerçektir. Yüce Allah, böyle sıkıntılı günlerde yalnız bırakmadığı Nebisini bazı hitaplarla teselli etmiş, bunu yaparken de "üzülmemesinin gerekçeleri" diyebileceğimiz bazı hususları ona hatırlatmıştır. Söz konusu hitaplarda önce bir peygamber olarak Muhammed (a.s.)' in sahip olduğu üstün konum kendisine anlatılmış ve daha sonra da inkarciların karakterleri tasvir edilerek, onların tarih boyunca peygamberlere benzer bir muhalefette bulundukları ifade edilmiştir.

Şimdi bu hususları daha ayrıntılı olarak inceleyelim:

\section{I - Hz. Peygamber'e Sahip Olduğu Konumu Hatırlatarak Teselli Verme}

İslâm dışı gruplar Peygamber (a.s.)'in tebliğinin ciddiyetini anlamak istememişler hatta bunu alay konusu yapmaktan da geri kalmamışlardır. Özellikle Mekke döneminde müşrikler tarafından gerek vahye ${ }^{65}$ gerekse Peygamber (a.s.)'in şahsına yöneltilen uygunsuz söz ve iftiralar yine Kur'ân tarafından reddedilmiştir. Meselâ Islâm dâvetine karşı gelen kâfirler,

65. Kur'ân hakkında müşriklerin. "Şâir ya da kâhinin sözü" şeklindeki iftiralarının reddedildił̧ âyetler için bkz: Hâkka (69): 41, 42. 
Peygamber (a.s.)'i deli ve kâhin olmakla suçladıklannda yüce Allah, şu hitap

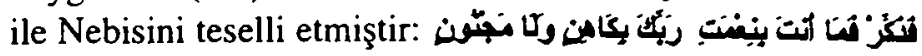

"(Ey Muhammed!) sen öğ̈̈t ver. Rabb'inin nimetiyle sen ne kâhinsin, ne de delisin." 60

Peygamber (a.s.)'e yöneltilen bu hitapla bize göre kastedilen şudur: Müşriklerin bu iddialarını biz reddediyoruz; senin bu iddialarla uğraşmana, onlara aldırmana gerek yoktur, sana düşen vazife tebliğ görevine devam etmektir.

Müşriklerin Peygamber (a.s.)'e yaptıklan sözlü sataşmalardan sonra onun İlâhî hitaplarla teselli edildiğini yukarıda ifâde etmiştik. Duhâ Sûresi'nin inişine sebep olan olay bu husus için bariz bir örnektir:

"Hz. Peygamber hastalanıp birkaç gün süreyle yatağından kalkamadığında yanına gelen bir kadın kendisine şöyle demiştir: 'Ey Muhammed! Gördüğüm kadarıyla şeytanın üç günden beri yanına uğramıyor, herhalde seni terk etti!" Peygamber (a.s.)'i çok üzen bu sözlerden sonra onu teselli eden şu hitap nazil olmuştur:67

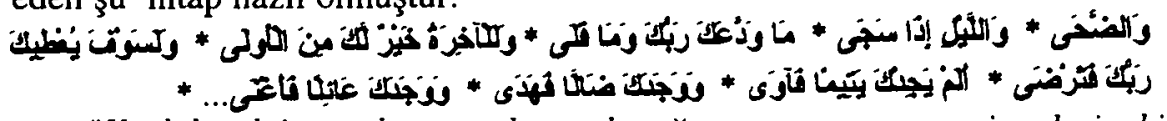

"Kusluk vaktine ve kararlp durgunlaştığ zaman geceye yemin ederim $k i$ $R a b b$ 'in seni terk etmedi ve sana darllmadl. Andolsun ki senin için ahiret dünyadan daha hayırlıdır. O seni yetim bulup barındırmadı mı? Şaşırmış bulup yol göstermedi mi? Fakir iken seni zengin etmedi mi? ..."68

Bu İlâhî hitap Allah Resûlü (a.s.)'nü pek çok yönden taltif etmekte ve onun yüce Allah tarafından hiçbir zaman terk edilmediğini açıkça ortaya koymaktadır.

Fahreddin er-Râzî (ö: 606/1209)'ye göre bu hitap Peygamber (a.s.) için büyük bir şereflendirmedir. Peygamber (a.s.) bu teselliyi çok büyük bir onur

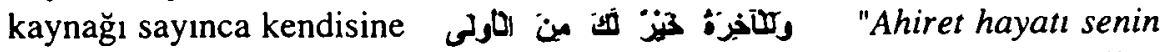
için dünyadan daha hayırlıdır" (Duhâ:4) denilmiştir. Böylece ona bahşedilen bu onur her ne kadar büyük olsa da, ideal şereflendirmenin ahirette olacağı yine kendisine müjdelenmiştir. ${ }^{69}$

Yine benzer başka bir hitapta Nebi (a.s.) şöyle teselli edilmektedir:

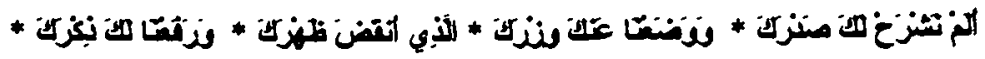

66. Tûr (52): 29.

67. Müslim, Cihad 39, (II. 1422). Bu hadisin farklı ibârelerle yapılan bir başka rivayeti için bkz: el-Buhârî, Tefsîr (Duhâ) 93, (IV. 86); et-Tirmîzî, Tefsîr (Duhâ) 93, (V. 442) Câmiü'l-beyân, XXX.231; Esbâbü'n-nüzûl, s. 481; Mefâtihüll-gayb, XXX. 210; Tefsîrü'l-Kur'âni'l-azîm. IV. 557; Lübâbü'n-nükûl, s. 244.

68. Duhâ (93): 1-8.

69. Mefâtîhü'l-gayb, XXXI. 210. 
"(Ey Muhammed!) senin göğsünü genişletmedik mi? Belini büken yükünü sırtından indirmedik mi? Senin şanını yüceltmedik mi? "70

$\mathrm{Bu}$ hitabın muhtevasından anlaşıldığı kadarıyla Islâm dâvetinin başlangıç döneminde Peygamber (a.s.) pek çok sorunla karşılaşmış ve sıkıntılı anlar geçirmiştir. Işste bu zor durumunda Cenâb-ı Hak kendisine şöyle demek istemiştir: "Ey Nebi! Biz sana lütufta bulunmadık mı? Buna rağmen başlangıçtaki zorluk dolayısıyla niçin perişan olmaktasın?"7ı

Ayette geçen: "Biz senin göğsünü açmadık mı?" hitabı hakkında şu yorum yapılmıştır: "Allah Resûlü, nübüvvetten önce Arap müşriklerin, Hristiyanların, Yahudilerin ve Mecusîler'in dinlerinin yanlış olduğuna inanıyordu. $\mathrm{O}$ aynı zamanda Araplar arasındaki karmaşık bir inanç yapısına sahip olan Haniflik'ten de memnun değildi. Bu sebeple kendisi zihnî bakımdan tereddüt içindeydi. İşte bu noktada yüce Allah nübüvvetle görevlendirdiği Elçisi'nin teredduitlerini gidermiş ve apaçık yolu göstererek ona tam anlamıyla tatmin olan bir kalp bahşetmiştir." 72

Bazı müfessirler bu hitapta geçen "Biz senin göğsünü açmadlk mı?" ifadesini, "Biz seni gamdan, kederden ve üzüntüden kurtarmadık mı?" şeklinde yorumlamışlardır. ${ }^{73}$

Kanaatimizce Kur'ân vahyi içerisinde Peygamber (a.s.)'e yöneltilen en bariz teselli hitâbı Kevser Sûresi'dir. Tek erkek çocuğu İbrahim'in ölümünden sonra müşriklerin kendisi için "soyu kesildi" şeklinde kullandıkları üzücü ifâdenin ardından nâzil olan ${ }^{74}$ şu teselli hitabı pek çok nimetin müjdecisi olmuştur:

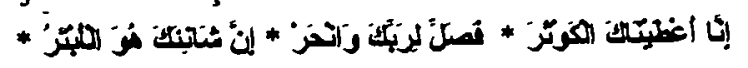

"(Ey Muhammed!) biz sana Kevser'i verdik. Öyleyse Rabb'in için namaz kıl ve kurban kes. Asıl soyu kesik olan sana buğzeden kimsedir."7s

70. Inşirah (94): 1-4.

71. Tefhîmü'l-Kur'ân, VII. 161.

72. A.g.e. VII. 162.

73. Bu konudaki göruşlerden birisine örnek olarak bkz: Mefâtîhü'l-gayb, XXXII. 3.

74. Kevser Sûresi'nin iniş sebebi için bkz: Esbâbü'n-nüzûl, s. 494, Ebû Muhammed Hưseyin b. Mes'ud el-Begavî, Meâlîmü't-tenzîl ve hakâiku't-te'vîl, Beyrut 1405/1985, IV. 504; Ebü'l-Ferec Cemaleddin Abdurrahman Ali b. Muhammed el-Cevzî, Zâdü'l-mesîr fi ilmi't-tefsîr, Beyrut 1407/1987, IX. 250; Mefâtihï'l-gayb, XXXII. 132; Celaleddin Abdurrahman b. Ebû Bekr es-Süyûtî, ed-Durrü'l-mensûr fi tefsîri'l-me'sûr, Beyrut 1410/1990, VI. 686; Muhammed Hamdi Yazır, Hak Dini Kur'ân Dili, Istanbul 1979, IX. 6178.

75. Kevser (108): 1-3. 
Bu ibârelerdeki "Kevser" kelimesi için, Cennet'te bir nehir, bol ilim, İslâm ümmetinin ve âlimlerinin çokluğu gibi tanımlar yapılmıştır. ${ }^{76}$

Gerçekten bugün Peygamber (a.s.)'in adını ananların çokluğunu ve soyunun kızı Fâtıma (ö:11/632) ile devam ettiğini, buna karşın ona "soyu kesik" diyenlerin de isimlerinin anılmadığını düşünürsek, bu İlâhî vaadin fiilen gerçekleştiğini söyleyebiliriz.

\section{2- Hz. Peygamber'e Inkarcuların Karakterlerini Haturlatarak Teselli Verme}

Kur'ân-ı Kerim'in daha ilk ayetlerinde inkarcı grupların kör, sağır ve dilsiz (doğruyu görmeyen, işitmeyen ve konuşmayan) oldukları vurgulanarak onların belirgin karakterleri tanımlanmıştır. ${ }^{77}$ Tarih boyunca Hakk'ın karşısına inkarında ısrar ve inat eden birtakım insanların çıktığı dolayısıyla onların bu inkar geleneğini her zaman ve her peygamber karşısında devam ettirdikleri gerçeği Kur'ân vahyi içerisinde sıkça tekrarlanmıştır. Bu gibi tarihî gerçeklerin vurgulandığı hitaplardaki asıl gâye; Peygamber (a.s.)'e verilmek istenen tesellinin devamlılığını ve dinamikliğini sağlamaktır. Meselâ inkarcıların $\mathrm{Hz}$. Nuh'a ve ondan sonra gelen elçilere inanmadıklarının anlatıldığı şu hitapta böyle bir vurgu bulunmaktadır:

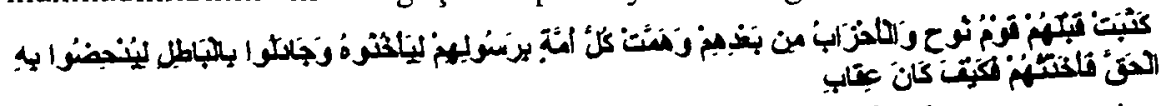

"(Ey Muhammed!) Onlardan önce Nûh kavmi ve onlardan sonra gelen gruplar da yalanladı. Her millet elçilerini yalanlamaya yeltendi ve hakkı gidermek için boş şeyler ileri sürerek tartıştllar. Bu yüzden onları yakaladım. (Bak işte) azâbım nasıl oldu?"78

Bize göre bu hitapta Nûh (a.s.) örneğinin seçilmesi önemlidir. Çünkü kâfirler dünyada gerçekleşen en büyük tarihî olaylardan birisi olan Tufan mucizesinin kahramanı $\mathrm{Hz}$. Nuh'a bile aldırmayarak inkar yolunu seçmişlerdi. Hatta ondan sonra gönderilen peygamberler döneminde bile bazı inkârcılar kutsal referanslarla kendilerine aktarılan bu hadiseden bir ders almadılar. Dolayısıyla bu hitapta: "Ey Muhammed! Sen de aynı tarzda bir mucize göstersen yine de onlara fayda vermez. $O$ halde bu inkârcılan ikna

76. Kevser" kelimesi için yapılan tanımlar için bkz: Ebû Zekeriyyâ Yahya b. Ziyâd el-Ferrâ, Meâni'l-Kur'ân, Beyrut 1408/1988, s.369; Ebû Ca'fer Ahmed b. Muhammed en-Nahhâs, I'râbü'l-Kur'ân, Beyrut 1408/1988; V.298; Lisânü'l-Arab, IV.131; Tâcü'l-arûs, IV.517. Bu konudaki bütün göruşler için aynca bkz: M. Fatih Kesler, Kur'ân-ı Kerim'de (Mâûn ve Kevser Sûrelerinde) Insan Tipleri, Ankara 1995, s.66-72.

77. dönmezler." Bakara (2):18.

78. Mư'min (40): 5 . 
etmek için uğraşma, zamanını boşa harcama ve hiçbir değeri olmayan bu insanlara aldırma!" denildiği düşünülebilir.

Bazı hitaplarda Hz. Peygamber'in, inkarcılara aldırış etmemesi sıkça vurgulanırken bu husustaki gerekçeler de aynı şekilde çoğalıılmakta ve somutlaştırılmaktadır. Meselâ bu bağlamdaki bir başka teselli hitabı ve gerekçesi şöyledir:

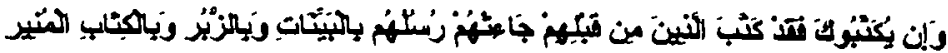

"Ĕger bu inkârcilar seni yalanliyorlarsa üzülme! Çünkü bunlardan öncekiler de yalanlamışlardi. Elçileri onlara açık deliller, sayfalar ve aydınlatıcı kitâp getirmişlerdi, yine de onları yalanladılar."79

Buradaki ifâdeler imansızlıklarını inatla sürdüren insanlara açık delil ve aydınlatıcı bilginin fayda vermeyeceğini dolayısıyla onların sonunda, inkârlarının cezasının göreceklerini ortaya koymaktadır. O halde iman etmek için bazı deliller isteyen inkârcıların bu türden isteklerini yerine getirme hususunda Peygamber (a.s.) kendisini zorlamamalı ve onların iman etmek karşılığında yönelttikleri her soruya cevap vermemelidir. Bu llâhî istem Kur'ân'ın tenzil sürecindeki bir takım tarihî olaylarla da teyit edilmiştir. Meselâ bir grup müşrikin, Ashâb-1 Kehf ve benzeri konularda yönelttiği bazı sorulara vahiy ile cevap vermeyi düşünen Nebi (a.s.), kendilerine, "Bu sorularınızı yarın cevaplandıracağım" diye karşlık vermiş ancak, "Allah izin verirse" ifadesini kullanmamıştır. Sonuçta beklediği vahiy zamanında gelmeyince buna çok üzülmüştür; çünkü İslâm dışı gruplar bu hususu istismar edip dedi-kodu yapmaya başlamışlard. Nihayet beklenen vahiy, daha sonra şu teselli hitabı sarmalıyla inzal olmuştur:80

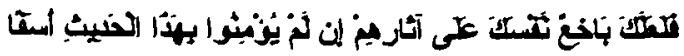

"(Ey Muhammed!) Bu söze (Kur'ân'a) inanmazlarsa herhalde onların ardinca sen de üzüntüden kendini tüketeceksin."81

Peygamber (a.s.)'in beklediği vahyin gecikmesine onun "İnşallah" ifadesini kullanmadan müşriklere yaptığı vaadin sebep olduğunu söylemek bir izah tarzı olabilir. Fakat bize göre bu gecikme olayında önemli olan şey, Cenâb-ı Hakk'ın yukarıda da ifade ettiğimiz üzere Nebisinin inkarcılara ve onların sorularına itibar etmemesini istemesidir. Nitekim İlâhî irade, bu istemini ilgili konudaki vahyi geciktirerek göstermiş ve böylece Peygamber

79. Fâtır (35): 25.

80. Anlattığımız olay hakkında daha geniş bilgi için bkz: Lübâbü'n-nükûl, s. 183.

81. Kehf (18): 6 . Buna benzer bir başka âyette ise şöyle denilmektedir:

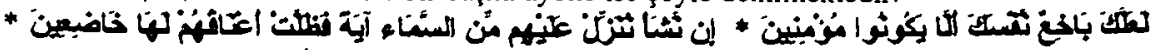

"Ey Muhammed!' Inanmiyorlar diye neredeyse kendini kahredeceksin. Biz dilersek gökten bir mucize indiririz de ona boyun eğip kalırlar." Şuarâ (26):3,4. 
(a.s.)'in İslâm dışı grupların istekleri karşısında takınacağı tavrı da belirlemiştir. İncelediğimiz âyetlerde Peygamber (a.s.)'i İslâm dışı gruplar karşısında rahatlatacak cevapların bulunması her ne kadar birer teselli görünümü verse bile bu âyetlerin total bir şekilde gecikmeli olarak indirilmesi bu hitabın aynı zamanda bir ikazı da içerdiğini göstermektedir. Aslında Nebi (a.s.)'nin teselli edildiği bazı hitaplarda da buna benzer çağrışımlar bulmak mümkündür. Bu bağlamda teselli ve ikazın iç içe olduğu hitaplardan birisi de şudur:

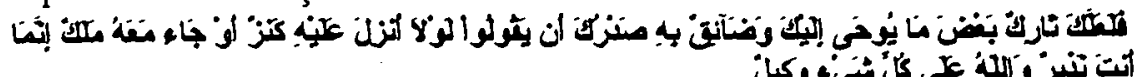

"Herhalde sen 'Ona bir hazîne indirmeli veya beraberinde bir melek gelmeli değil miydi?' demelerinden ötürü sana vahyolunanın bir kısmını birakacaksın ve bununla göğsün sıkılacak. Sen sâdece bir uyarıcısın (böyle sözlere aldırma) her şeye vekil olan Allah'tır."82

Bu hitapta Peygamber (a.s.)'e yapılan tesellinin yanı sıra kanaatimizce ona şöyle bir mesaj da verilmek istenmiştir: "Ey Muhammed! Sen sâdece bir elçisin sana indirilenin bir kısmı inkarcılann hoşuna gitmeyebilir, ancak sen, içinde bulunduğun şartlara aldırmaksızın görevine devam et."

Bu türden hitaplara ömek olarak verebileceğimiz bir başka âyet grubu da şudur:

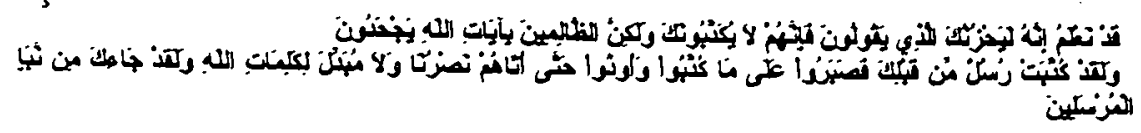

"Onların dediklerinin hakikaten seni üzmekte olduğunu biliyoruz. Aslında onlar seni yalanlamiyorlar fakat bu zalimler bile bile Allah'in âyetlerini inkar ediyorlar. Senden önce de birçok elçi yalanlandı. Kendilerine yardımımız gelene kadar yalanlanmaya ve incitilmeye katlandılar. Allah'ın sözlerini değiştirecek kimse yoktur. Bu elçilerin haberi sana da gelmiştir." 83

Teselli içerikli bu hitapta kâfirlerin inkarlarının sebeplerinin Peygamber (a.s.)'in şahsından kaynaklanan herhangi bir olaya dayanmadığı dolayısıyla onun bu açıdan müsterih olması istenmektedir. Bu hitapta yer alan: "Aslında onlar seni yalanlamıyorlar..." şeklindeki teselli ibaresi inkarcılardan bazılarının Peygamber (a.s.)'in şahsına yönelik bir takım sözlerine işaret etmekte ve onu bu yolla da teselli etmektedir. Bununla ilgili olarak rivâyet edilen olay şudur: "Bir gün Ebû Cehil, Peygamber (a.s.)'e gelerek şöyle dedi: 'Ey Muhammed! Biz seni yalanlamıyoruz; çünkü sen bize göre doğru bir

82. Hûd (11): 12.

83. En'âm (6): 33,34 . 
kimsesin. Ama biz senin getirdiklerini yalanlıyoruz.' İşte onun bu konuşmasından sonra yukarıdaki âyet nâzil olmuştur." ${ }^{\text {"8 }}$

$\mathrm{Bu}$ âyette ayrıca Nebi (a.s.)'nin, çevresindeki inkarcıların tavırları karşısında üzülmemesi gerektiği bir kez daha vurgulanmakta ve daha önceki peygamberler gibi onun da Allah'in yardımı gelinceye kadar bu türden şeylere sabretmesi istenmektedir.

\section{Değerlendirme}

"Dünya Ínsanlık Ailesini" yeniden vahiyle tanıştırmak ve bu doğrultuda eğitmekle görevli olan $\mathrm{Hz}$. Peygamber'i, deruhte ettiği görevi esnasında oldukça sıkıntılı bir sürecin sarmaladığı bilinmektedir. Seçtiği kulunu böyle bir ortamda yalnız bırakmayarak kesintisiz bir eğitime tâbi tutan yüce Allah, hayatın bütün yansımalarına karşı onu teçhiz etmiştir. Kutsal bir eğitim ve Rabbânî destek ile gerçekleşen bu aktivite vahiyle tanışık örnek bir toplumun inşasına kadar sürmüştür.

Kur'ân'ın tenzil süreci boyunca eğitilen bu seçme kula, çeşitli konuları ihtiva eden bir takım hitaplar da tevdi edilmiştir. Vahyin zinde gücü konumundaki söz konusu bu bildirimler genel olarak Nebi (a.s.)'ye yakın bir diyalog formunda nazil olmuştur. Anılan süreçte istikrar bulan nübüvvet misyonunun birer gözetmeni durumundaki bu İlâhî reflekslerin gayesi; nebevî aktiviteleri çeşitli ayak sürçmelerinden arındırmak böylece $\mathrm{Hz}$. Peygamber'in seçkin konumunun başlangıçtaki İlâhî doğrultuda devam etmesini sağlamaktır.

Ilâhî irâde, bu hitaplanı bazen ona verilen bir emir bazen ikaz bazen de aşması gereken bir takım sıkıntılar karşısında sahip olduğu üstün konumu ve elde ettiği nimetleri kendisine hatırlatan teselli şeklinde nazil etmiştir. Dolayısıyla bu müdahaleci vahiy kesitleri, çeşitli beşerî tecrübeler karşısında hiçbir zaman yalnız bırakılmayan ve en yüce makamdan sürekli olarak eğitim alan bir elçinin geniş kitlelerce örnek alınmasının haklı gerekçelerini oluşturmuşlardır.

Seçilmiş bir insanda olmaması gereken en küçük bir fazlalığı izale etmeyi, veya mevcut olmayan bir şeyi ona kazandırmayı hedefleyen bu Illâhî bildirimler, Hz. Peygamber'in konumunu erişilmez kılmıştır. Zaten İlâhî irâdenin son nebi ve insanlık için bir arınma fırsatı olarak seçtiği Muhammed (a.s.)'e gösterdiği ilgi ve ona kazandırdığı bu saygın konum son vahyin selameti açısından da elzemdir. Bu metotla yüce Allah, korunmasını

84. et-Tirmîzî, Tefsîr (En'âm) 7, (V. 261); Esbâbü'n-nüzû'l, s. 219; Lübâbü'n-nükûl, s. 123; el-Câmi'li ahkâmi'l-Kur'ân, VI. 416; Tefsîrï'l-Kur'âni'l-azîm, II. 134; Tefhîmü'lKur'ân, I. 544. Ayrıca bir başka rivâyet için bkz: Câmiü'l-beyân, VII. 182. 
üstlendiği Kur'ân'ı insanlara ulaştırıp açıklaması için kendisine emanet olarak verdiği Nebi'sini gözetim altında tutmuştur. Böylece vahiy, sadece inkarcıların tahrif teşebbüslerine karşı değil aynı zamanda onu tebliğ eden Peygamber'in beşer̂ meyillerine, Peygamber'i bulunduğu konumdan çıkartan hatta ona ilahlık nispet edenlerin iğvalarına, şu ya da bu şekilde kendisini etkilemek isteyen insan ve cin şeytanlarına karşı da korumuştur.

Öyleyse, yüce Allah'ın, son nebisiyle kurduğu bu yakın diyaloğların, bu esnada gerçekleştirdiği İlâhî reflekslerin ve uyguladığı şokların birer formu olan hitaplanı bu açıdan değerlendirmek gerekir.

\section{BIBBLIYOGRAFYA}

ABDÜLBÂKİ, Muhammed Fuâd, el-Mu'cemü'l-müfehres lî elfâzi'l-Kur'âni'l-kerim, İstanbul tSZ.

AHMED b. Hanbel, Ebû Abdullah Muhammed eş-Şeybânî (ö:241/855), el-Müsned, Beyrut tsz.

el-BEGAVÎ, Ebû Muhammed Hüseyin b. Mes'ud (ö:516/1122), Meâlimu't-tenzîl ve hakâiku't-te'vîl, Beyrut 1405/1985.

el-BEYDÂVÎ, Kadı Nâsıruddîn Ebû Saîd Abdullah b. Ömer (ö:791/1388), Envârü't-tenzîl ve esrârü't-tevîl, Beyrut tsz.

el-BUHÂRî, Ebû Abdullah Muhammed b. İsmâil (ö:256/869), Câmiü's-sahîh, İstanbul 1401/ 1981.

EBU DÂVÛD. Sülcyman b. el-Eş'âs es-Sicistânî (ö:275/888), es-Sünen, İstanbul 1401/ 1981.

el-FERRÂ, Ebû Zckeriyyâ Yahya b. Ziyâd (ö:207/822), Meâni'l-Kur'ân, Beyrut 1408/198

HÂKIM, Ebû Abdullah Muhammed b. Abdullah en-Nîsâbûrî (ö:405/1014), el-Müstedre ale's Sahiheyn, thk: Mustafa Abdulkadir Atâ, Bcyrut 1411/1991.

el-HEYSEMÎ, Nureddin Ali b. Ebû Bekr (ö:807/1404), Mecmeü'z-zevâid ve menbeü'l-fevâid, Beyrut 1402/1982.

İBN KESÎR, İmâdưddin Ebư'l-Fidâ İsmail b. Ömer (ö:774/1372), Tefsîrü'l-Kur'âni'l-azîm, Beyrut 1412/1992.

IBN MÂCE, Ebû Abdullah Muhammed b. Yezîd el-Kazvînî (ö:273/886), es-Sünen, Istanbul $1401 / 1981$.

IBN MANZÛR, Ebü'l Fazl Cemaleddin Muhammed b. Mükerrem (ö:711/1311), Lisânü'lArab, Misır tsz.

IBNÜ'L-CEVZî, Ebü'l-Ferec Cemaleddin Abdurrahman b. Ali b. Muhammed (ö:597/1200), Zâdü'l-mesîr fi ilmi't-tefsîr. Beyrut 1407/1987.

tBNÜ'L-ESÎR, İzzeddin Ebü'l Hasan Ali b. Muhammed (ö:606/1209), el-Kâmil fi't-târih. Beyrut 1399/1979.

KESLER, M. Fatih, Kur'ân-ı Kerim'de (Mâûn ve Kevser Sûrelerinde) Insan Tipleri, Ankara 1995.

el-KURTUBÎ, Ebû Abdullah Muhammed b. Ahmed (ö:671/1272), el-Câmi'li ahkâmi'lKur'ân, Kahire tsz.

el-MEVDÛDî, Ebü'l-A 'lâ (ö:1399/1979). Tefhîmü'l-Kur'ân-Kur'ân'in Anlamı ve Tefsiri, trc: Komisyon, İstanbul 1996.

MÜSLIM, Ebü'l-Hüseyin Müslim b. el-Haccâc el-Kuşeyñ en-Nîsâbûn (ö:261/874), Câmiü'ssahîh, İstanbul 1401/1981. 
en-NAHHÂS, Ebû Ca'fer Ahmed b. Muhammed (ö:338/949), I'râbü'l-Kur'ân, Beyrut 1408/ 1988.

en-NESẦ̂, Ebû Abdurrahman Ahmed b. Şuayb (ö:303/915). es-Sünen, İstanbul 1401/1981.

er-RÂZÎ, Fahreddin Muhammed b. Ömer (ö:606/1209), Mefâtîhül-gayb, Bcyrut tsz.

es-SÜYÛTÎ, Celaleddin Abdurrahman b. Ebû Bekr (ö:910/1505), el-likân fi ulîmi'l-Kur'ân, İstanbul 1398/1978.

-...-., ed-Dürrü'l-mensûr fî tefsîrî' l-me'sûr, Beyrut 1410/1990.

--.--, Lübâbü'n-nuikûl fi esbâbi'n-nüzûl, Beyrut tsz.

et-TABERÂNî, Ebü'l Kâsım Süleyman b. Ahmed (ö:360/971), el-Mu'cemü'l-kebîr, thk Hamdi Abdulmecîd es-Selefi, byy. tsz.

et-TABERÎ, Ebû Ca'fer Muhammed b. Cerîr (ö:310/923), Câmiä'l-beyân an te'víli âyi'lKur'ân, Beyrut 1408/1988.

et-TÂCi, Ahmed, Vahyü's-sîre, Misır 1401/1981.

et-TiRMî̉î, Ebû İsâ Muhammed b. İsâ (ö:279/892), Câmï̈'s-sahîh, İstanbul 1401/1981.

el-VÂHtDî, Ebü'l Hasan Ali b. Ahmed en-Nîsâbûn (ö:468/1075), Esbâbü'n-nüz.ûl, thk Kemâl Besyûnî Zağlûl, Beyrut 1411/1991.

WENSICK, A.Y. (ö:1358/1939), Concordance et Indices de La Tradation Muslumane (elMu'cemü'l-müfehres-lî elfâzi'l-hadisi'n-nebevî), Haydarabat tsz.

YAZIR, Muhammed Hamdi (ö:1361/1942), Hak Dini Kur'ân Dili, İstanbul, 1979.

ez-ZEMAHŞERÎ. Ebü'l-Kâsım Cârullâh Mahmud b. Ömer (ö:538/1144), el-Keş̧âf an hakâiki't-tenzîl ve uyûni'l-ekâvîl fî vücûhi't-te'vîl, Beyrut tsz.

ez-ZEBÎDI, Muhammed Murtazâ (ö:1205/1790), Tâcü'l-arûs min cevâhiri'l-kâmus, Beyrut tsz.

ez-ZERKEŞî, Bedreddin Muhammed b. Abdullah (ö:794/1392), el-Burhân fî ulûmi'l-Kur'ân, Beyrut tsz. 